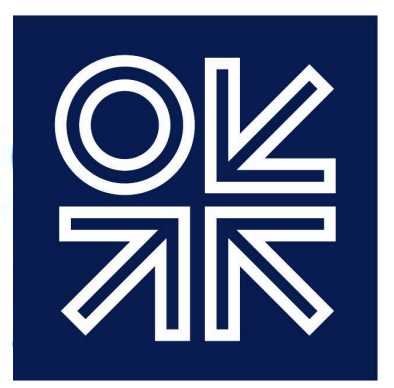

THE OXFORD INSTITUTE FOR ENERGY STUDIES

\title{
Is energy subsidy reform in an oil-exporting small economy beneficial to trade? Illustrations from Kuwait
}

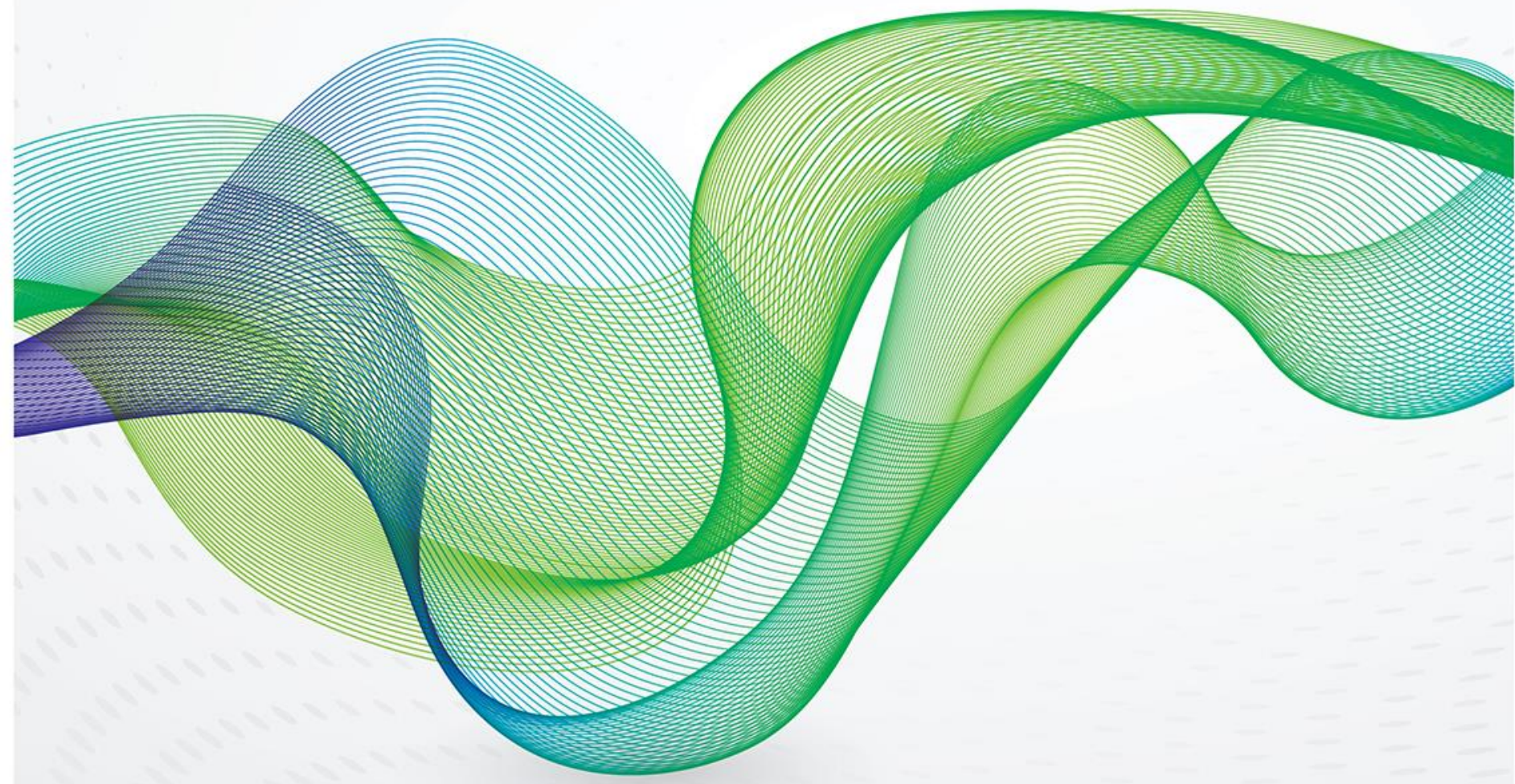



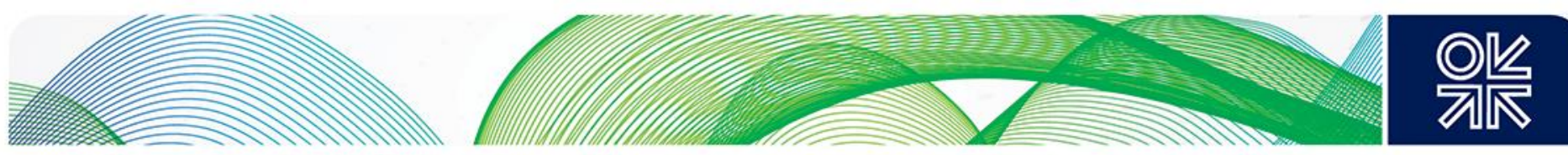

The contents of this paper are the authors' sole responsibility. They do not necessarily represent the views of the Oxford Institute for Energy Studies or any of its members.

\section{Copyright () 2019}

\section{Oxford Institute for Energy Studies}

(Registered Charity, No. 286084)

This publication may be reproduced in part for educational or non-profit purposes without special permission from the copyright holder, provided acknowledgment of the source is made. No use of this publication may be made for resale or for any other commercial purpose whatsoever without prior permission in writing from the Oxford Institute for Energy Studies.

ISBN 978-1-78467-127-3

DOI: https://doi.org/10.26889/9781784671273

OIES is grateful to the Kuwait Foundation for the Advancement of Sciences for funding support.

This is a follow up paper to Shehabi, M. 'Assessing Kuwaiti Energy Pricing Reforms' published by OIES in November 2017.

This paper was presented at the Trade Impacts of Fossil Fuel Subsidies Workshop 2018, organized by the Graduate Institute Geneva and the International Institute for Sustainable Development. The author is grateful for helpful comments from Workshop participants. 

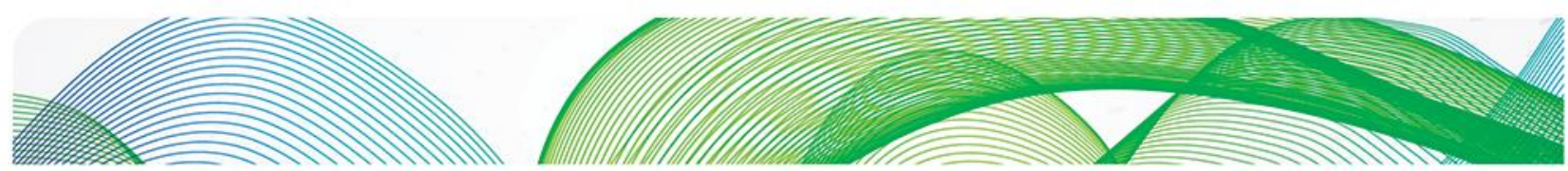
此

\section{Contents}

\section{Contents.}

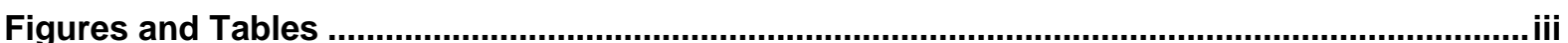

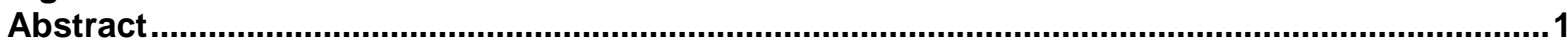

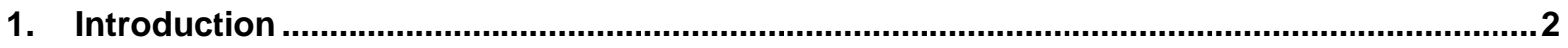

2. The Kuwaiti context ...................................................................................................... 4

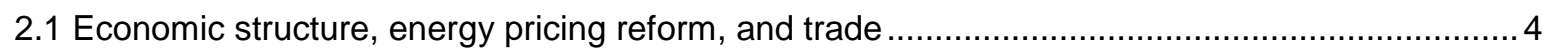

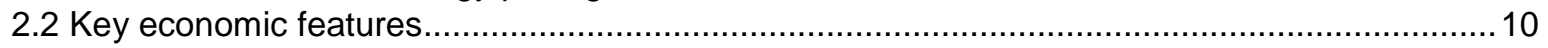

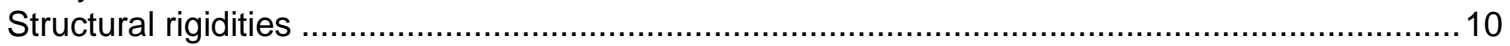

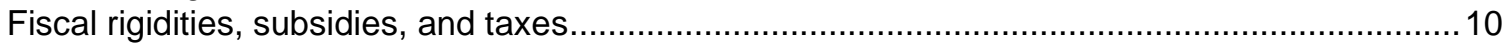

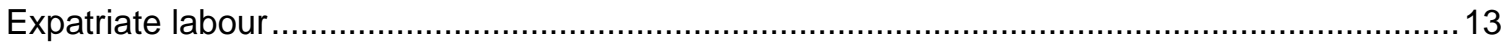

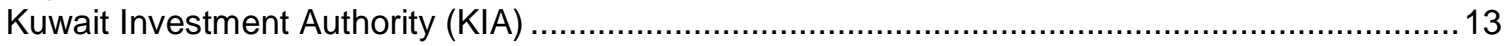

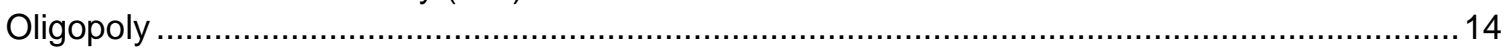

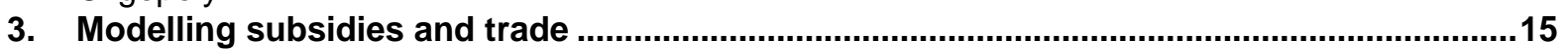

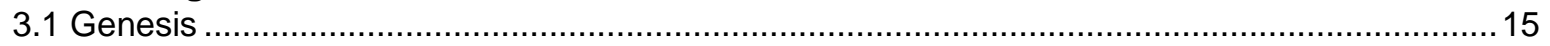

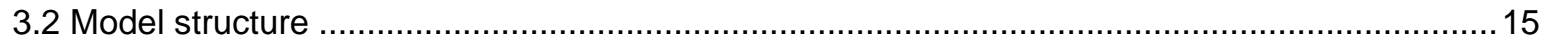

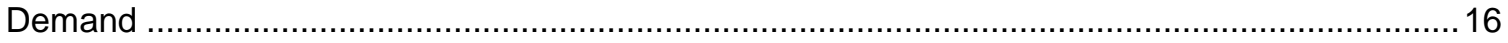

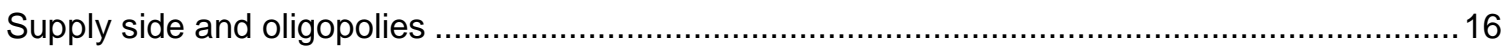

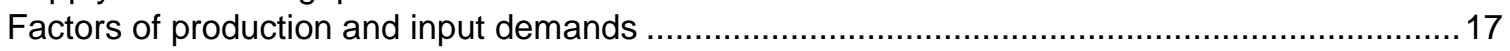

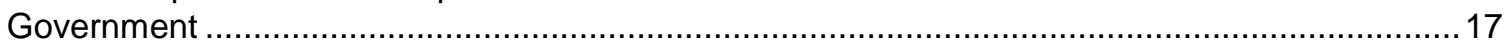

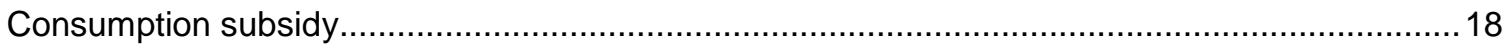

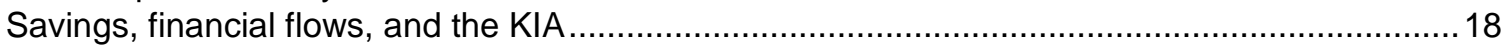

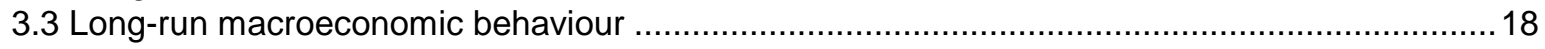

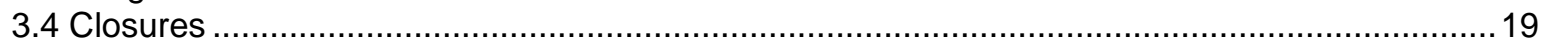

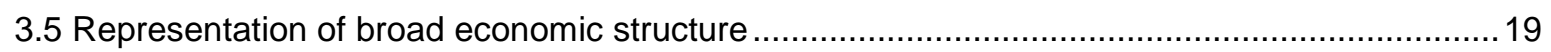

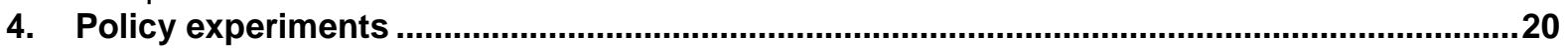

4.1 Scenario 1: energy subsidy reform in a high oil price environment allowing adjustments in fiscal

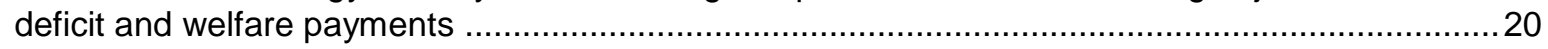

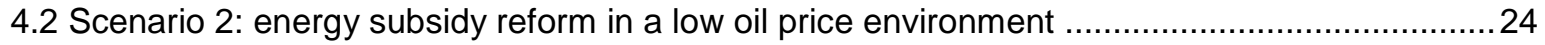

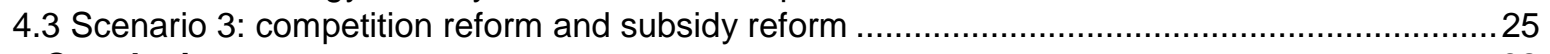

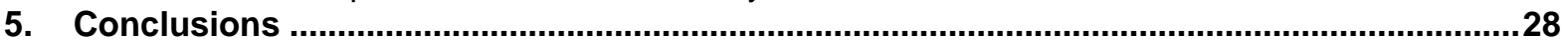

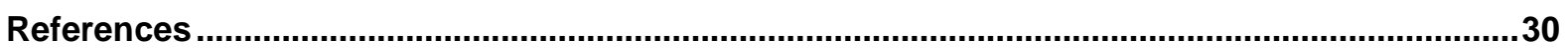

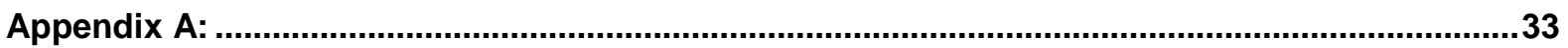

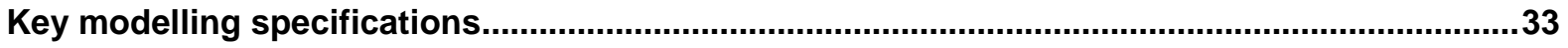

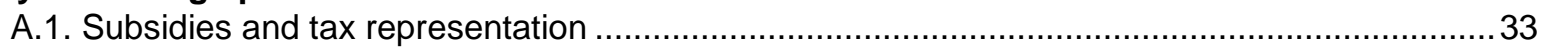

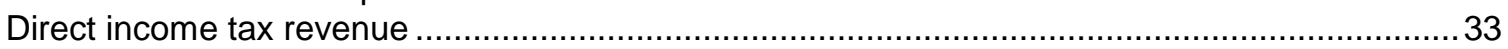

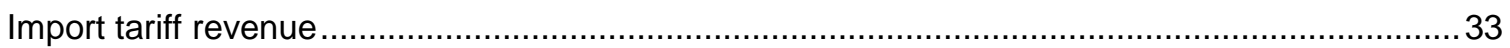

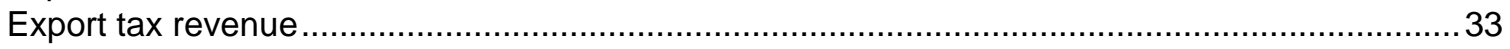

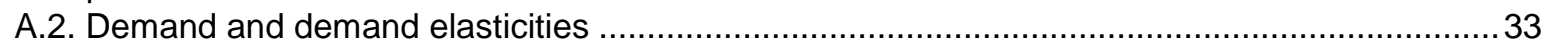

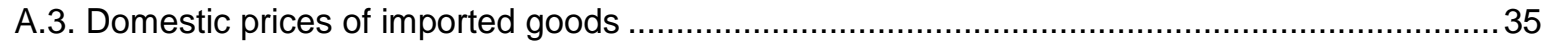

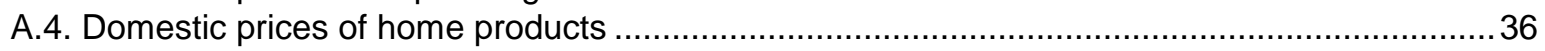

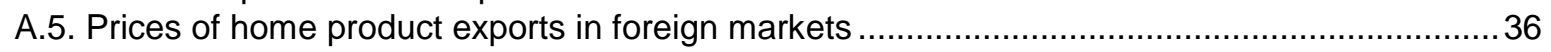

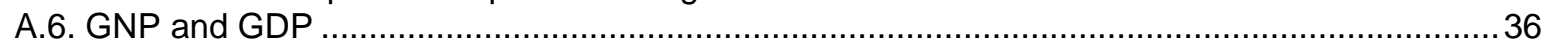

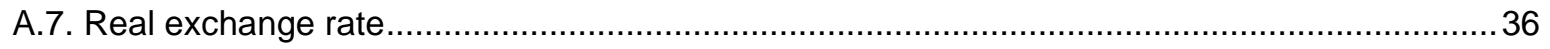



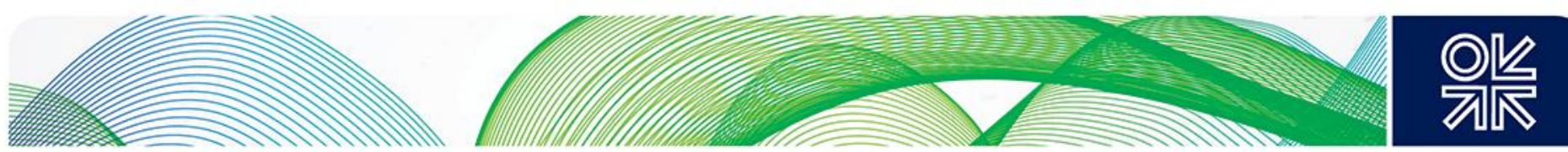

\section{Figures}

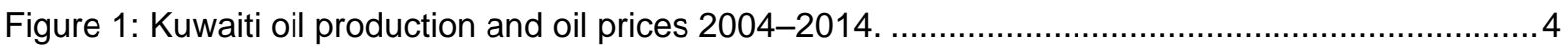

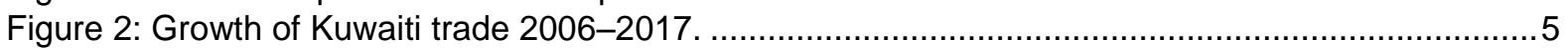

Figure 3: Kuwaiti non-hydrocarbon exports 2013-2017. ..........................................................

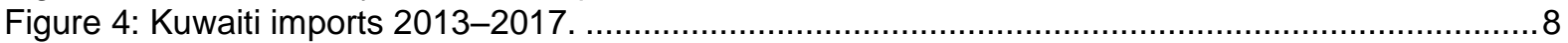

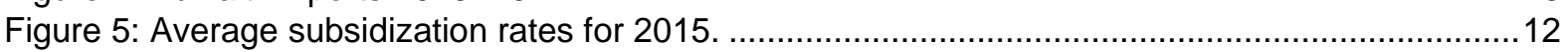

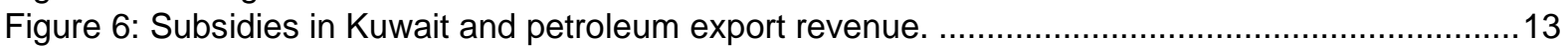

Figure 7: Cumulative Kuwaiti firm shares of industry...............................................................14

Figure 8: Comparative exports/GDP sectoral results of scenario 1 and scenario 3..........................27

Figure 9. Comparative expatriate employment sectoral results of scenario 1 and scenario $3 \ldots \ldots \ldots \ldots . .27$

\section{Tables}

Table 1: Economic structural elements 2013. 6

Table 2: Comparative values of key non-hydrocarbon Kuwaiti exports and imports 2013- 2017 .........9

Table 3. Value and composition of imports and exports 2013-2017 ...............................................

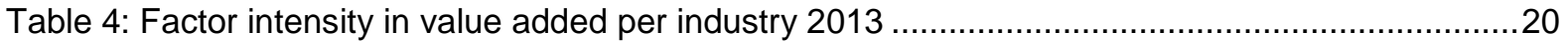

Table 5: Impact of energy subsidy reform shocks on selected economic variables in the long run .....21

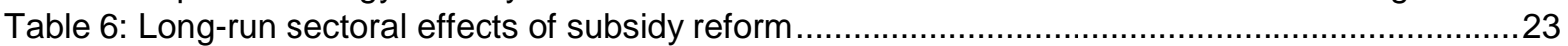

Table 7: Long- run sectoral effects of subsidy and competition reforms following oil price declines ...26

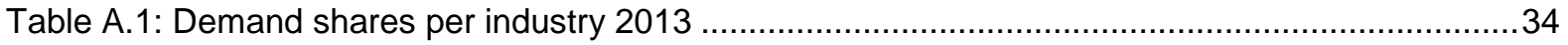

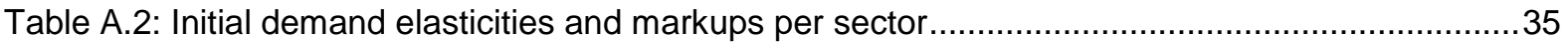



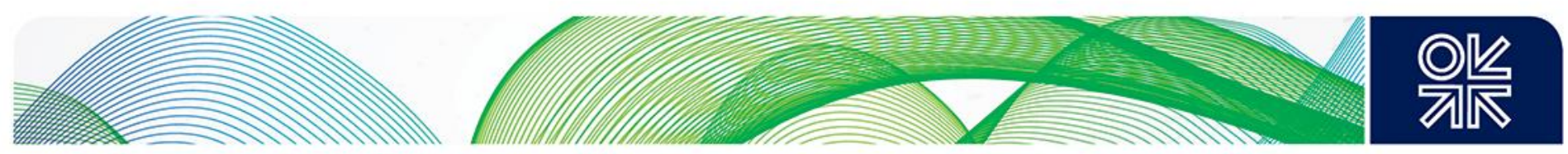

\begin{abstract}
Although pervasive, subsidies have long been accepted by economists as a generally inefficient, costly means of resource allocation that leads to wasteful consumption and distortion of international trade and local markets. Oil-exporting economies have adopted energy pricing reform since the collapse of the oil price in mid-2014, despite lingering fears that such efforts would hurt industries' competitiveness internationally. The World Trade Organization (WTO), a proponent of subsidy reform, has advanced that had targeted effectuating subsidy reform through the use of trade rules. Yet there is limited evidence on the linkages between trade and energy subsidy reform in the context of oil-exporting economies. This paper attempts to fill a gap in the literature by examining the impact of fossil fuel subsidy reform on trade (inflow and outflow) in an oil-producing, 'almost' small economy, focusing on the case of Kuwait. It employs a two-region economy-wide model with oligopoly behaviour to quantify the impact of Kuwaiti subsidy reform on trade. The model extends that of Shehabi (2017) by differentiating consumer- and industry-specific subsidy rates, and it also embodies unique elements of Kuwait's economic structure (rigidities) and distortions in its industrial structure and labour market. The results show that the impacts of subsidy reform on trade are driven by existing idiosyncratic economic rigidities and distortions. Simulations clarify the fact that energy production subsidies have minimal effect on the international competitiveness of Kuwaiti non-energy sectors, due to the pervasiveness of oligopolies that sustain large markups and collusive pricing. As such, contrary to what the WTO's polices suggest, the expansion of non-oil exports is constrained in its ability to moderate reform impacts in a low oil price environment due to institutional, political, and economic constraints. Yet with appropriate incentives, such dynamics could be considerably more effective-leading to potential expansion. Subsidy reforms have higher pro-trade effects if implemented in a low oil price environment because their negative effects are partially offset by efficiency gains and reduction in oligopoly markups. The analysis shows that in developing oil exporting economies characterized by pervasiveness of oligopolies, microeconomic reform can be a channel through which the pro-trade effects of energy subsidy reform can be achieved. The results have great policy implications, including that organizations like the WTO should use benefits other than non-energy expansion to encourage oil economies to reform energy subsidies.
\end{abstract}

JEL classification: C68, D43, D58, E24, E62, F41, H50, L13, L43, O53, Q43

Keywords: fossil fuel; subsidy; trade; general equilibrium; oil exporter; oligopoly; sovereign wealth fund; expatriate labour; Kuwait, CGE. 


\section{Introduction}

Fossil fuel subsidies have been widely accepted by economists as being distortionary (Plante, 2014) and a generally inefficient, costly means of resource allocation that leads to wasteful consumption and distortions in international trade and local markets. Such impacts have motivated international organizations such as the G7, the G20, and the Asia-Pacific Economic Cooperation (APEC) to draw commitments from various member countries to reduce fossil fuel subsidies. Given the estimated impact of subsidies on trade, the Centre for Trade and Sustainable Development (ICTSD) and the World Trade Organization (WTO) have targeted effectuating subsidy reform through the use of trade rules.

Energy pricing reform has also gained ground across major oil exporting economies, as high subsidies were blamed for aggravating the severe fiscal challenges caused by the collapse of the oil price in mid2014. Nevertheless, barriers to reform persist, and subsidies remain high. According to the International Energy Agency (2018), fossil fuel consumption subsidies increased by 12 per cent in 2017 to reach US $\$ 300$ million, more than half of which is accounted for by 11 of the major oil producing economies. ${ }^{1}$ Barriers to reform have included concerns over inflationary pressures (due to the rising cost of energy sources both as an input and a final good), as well as over the industrial competitiveness of the exportoriented sectors necessary for economic diversification (IMF, 2013).

Importantly, in the literature on oil-exporting economies, while studies on the impact of energy subsidy reform on welfare and the macroeconomy offer inconclusive evidence and have been rising in number (Gahvari \& Taheripour, 2011; Arze Del Granado et al., 2012; BuShehri \& Wohlgenant, 2012; Lin \& Li, 2012; Fattouh \& Mahadeva; 2014; Dennis, 2016; Rentschler, 2016; Li, Shi, \& Su, 2017; Shehabi, 2017; Gelan, 2018), little is known about the impact of energy subsidy reform on the trade and competitiveness of these economies. In general terms, subsidies impact competitiveness and trade via two main mechanisms: first, via prices of final and intermediate goods; and, second, via the real exchange rate, which affects trade flows (both imports and exports). In the context of Nigeria, Bazilian and Onyeji (2012) show that fossil fuel subsidy removal in energy-poor countries reduces competitiveness for businesses impaired by power supply deficiencies. Using a generic general equilibrium model with constant returns to scale, Jensen and Tarr (2003) find that subsidy reform and trade reform achieve large welfare gains, respectively but the impact of the former on the latter is not examined. In the context of highly specialized economies such as those of the Gulf region, proponents of energy subsidy reform have stipulated that in a low oil price environment it would lead to the expansion of non-oil sectors and their exports. This is the logic of the WTO's use of trade rules to reform subsidies. Sceptics, however, argue that subsidy reform would result in minimal changes to either the economic structure or trade in these economies, due to the dominance of the oil sector in them and, consequently, that the prospects for expansion opportunities in the non-oil sector and its exports are limited.

To examine these two views, and given the gaps in the literature, this paper examines the impact of fossil fuel subsidy reform on trade (inflow and outflow) in an oil-exporting, distorted, 'almost' small economy, showing illustrations from Kuwait. Specifically, this paper asks two primary questions: (i) do production subsidies offer non-energy Kuwaiti industries an advantage in the international market?; and (ii) what are the linkages between energy subsidy reform and trade in a low oil price environment? Economy-wide models are best suited to offer such insights, because answering these central questions requires capturing the interactions between industries in a second-best environment, which can be only measured by economy-wide CGE models. Yet only a few such models of Kuwait's economy exist. The models of Alsabah (1985) and Khorshid $(1990,1991)$ are dated. The more recent model of 
Gelan (2018) uses the International Food Policy Research Institute (IFPRI) standard CGE model ${ }^{2}$ with Kuwaiti data and does not reflect recent economic features or current market conditions. In contrast, Shehabi (2017) constructs an economy-wide model in a CGE framework that explicitly incorporates oligopoly behaviour and embodies key economic features of the Kuwaiti economy; however, its representation of subsidies uses a homogeneous subsidy rate across industries, which limits the ability to offer insights relating to economic impacts on specific sectors.

To tackle the aforementioned questions, this paper employs a two-region economy-wide, general equilibrium model with oligopolistic behaviour that embodies key features of Kuwait's contemporary economy and extends the model of Shehabi (2017) by differentiating consumer- and industry-specific energy subsidy rates. The model embodies key unique features of the Kuwaiti economy which are: high specialization in petroleum sector activity; dominance of the public sector in the economy; dominance of expatriate labour across the economy, particularly in the private sector; large consumption and industrial subsidies; investments into and withdrawals from the sovereign wealth funds; and oligopolistic industrial structures. The key motivation behind extending Shehabi (2017) is the importance of oligopolistic behaviour in small economies where industrial output tends to be below minimum efficient scale.

This paper makes important contributions to the literature by understanding the linkages between trade and subsidy reform in distorted, highly specialized, small open oil economies. Based on available information, this paper is the only applied GE study in which trade emerges as a central issue in the context of the Middle East. In the context of current literature on the MENA economies, this model offers new insights on whether subsidy reform offers pro-trade impacts, and it also offers a unique perspective on oligopolistic behaviour, its regulation, and the management of both oil and non-oil oligopoly rents. The Kuwaiti economy is chosen as the illustrative case as it offers various parallels with distorted oil economies having similar high levels of distortions, and with others having similar economic structures. Not only is the Kuwaiti economy highly specialized-with the oil sector constituting more than 62 per cent of GDP and more than 90 per cent of exports, estimated at US $\$ 41$ billion in 2016 -it also exhibits one of the highest energy price distortions, estimated at US $\$ 41$ billion in 2016 , with an annual subsidy per capita of US\$1,547 in 2015 (the highest globally) (EIA, 2017).

In the subsequent analyses, three experiments are undertaken, all analysed in the long run: (a) a counterfactual decline in energy subsidy rates in a high oil price environment without change in any policy instruments; (b) the first shock in experiment (a) combined with a decline in the oil price (this is similar to the position in Kuwait following the implementation of energy pricing reform in August 2016; and (c) both shocks in experiment (b) combined with a hypothetical microeconomic policy reform. Four major findings emerge from the simulation results.

1. The effects of subsidy reform on trade in a highly specialized and distorted economy are negative and occur through the two aforementioned main channels (raising costs of final goods and appreciating the real exchange rate) which have opposite effects on industries, but their impact is significantly limited in Kuwait by four existing idiosyncratic economic rigidities. These factors are: rigid public sector employment, oligopolistic distortions, high dependence on imported intermediate inputs in local production, and the limitations of capital movement-as capital is largely locked in public industries or sovereign wealth funds abroad. When subsidy reform is implemented, such economic and structural constraints persist. These factors, coupled with the low elasticity of substitution between imports and locally produced goods, mean that any expansion in those sectors is small.

2. In relation to concern over the erosion of industrial competitiveness: while energy production subsidies reduce the costs of non-oil sectors, they lead to minimal improvements in their international competitiveness due to their oligopolistic nature and their collusive pricing in the economy. These factors enable the non-oil sectors to sustain large markups 
in domestic markets and offer little incentive to export. As such, there are few incentives for efficiency-enhancing structural change.

3. Subsidy reforms have higher pro-trade effects if implemented in a low oil price environment because their negative effects (in the first finding) are partially offset by efficiency gains and reduction in oligopoly markups. These gains occur as non-oil industries are directed away from the least elastic (intermediate and investment) demand to the more elastic (export and final) demand.

4. Subsidy reform worsens the competitive gains of the non-oil exporting industries in a low oil price environment, but in combination with microeconomic reform that manages competition, sustained benefits and structural changes can be achieved in the long run, enabling the creation of opportunities for increased efficiency and expansion of the private sector and non-oil exports. The results potentially suggest a lesson in the sequencing of reforms and confirm that in developing oil-exporting economies that are characterized by the pervasiveness of oligopolies, microeconomic reform can be a channel through which the pro-trade effects of energy subsidy reform can be achieved.

Therefore, contrary to what the WTO policies suggest, subsidy reform in highly specialized oligopolistic oil economies does not lead to pro-trade expansion due to economic and structural constraints, a result which has direct policy implications. This result has important policy implications, as detailed below.

The rest of the paper is organized as follows. Section 2 summarizes Kuwait's economy, trade profile, and energy pricing developments. Salient details of the model follow in Section 3. Section 4 summarizes scenarios of empirical applications of the model and their results. The concluding Section 5 reveals various tradeoffs and policy lessons.

\section{The Kuwaiti context}

\subsection{Economic structure, energy pricing reform, and trade}

Like many oil-exporting economies, Kuwait's economic development strategy since the 1960s has positioned crude and refined oil products at the forefront of its exports and government revenue. As a result, the country's GDP is closely linked to its oil production and oil prices, as Figure 1 illustrates, and, it is therefore, subject to oil price volatility.

\section{Figure 1: Kuwaiti oil production and oil prices 2004-2014.}

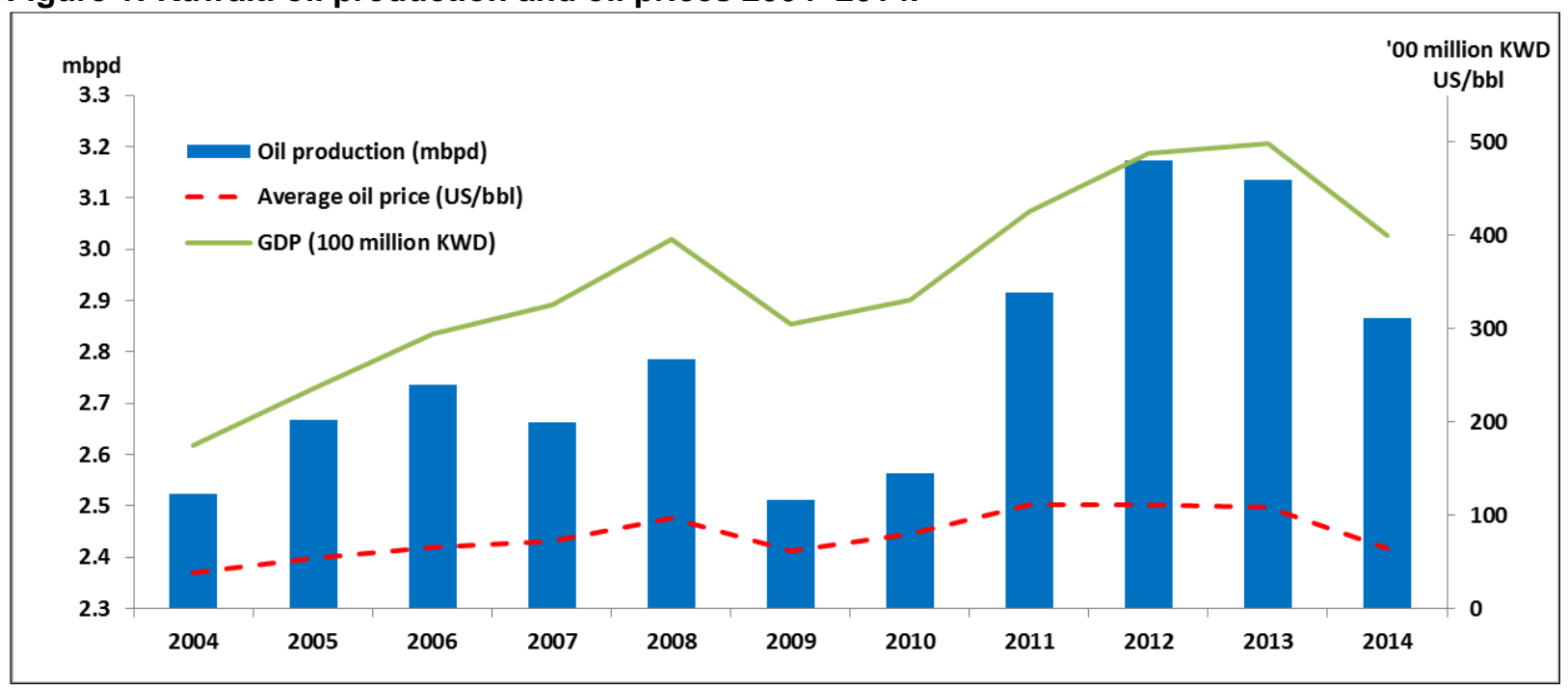

Source: Author's calculations based on data from Kuwait Central Statistical Bureau [CSB] (2017a), BP Statistical Review of World Energy, and EIA. 
Kuwait's hydrocarbon production is managed through the state-owned Kuwait Petroleum Company (KPC), and oil production is formally determined by OPEC's production allocations, set at 2.7 million barrels per day (mbpd) effective January 2017 (OPEC, 2017). Actual production varies, but hovered around $3.1 \mathrm{mbpd}$ between 2012 and 2017 (BP, 2018). Kuwait follows a seemingly export-led growth policy in a welfare state with high government intervention. The country's primary macroeconomic objective has been the maintenance of low inflation (1.5 per cent), which has been partly achieved through a monetary policy tied to its stable currency, which is pegged to a basket of reserve currencies. It relied on fiscal policies as its main instrument of macroeconomic stabilization, aided by substantial foreign asset accumulation in its sovereign wealth funds (SWFs). The high levels of oil rent to date have seen the country enjoy striking levels of wealth, impressive foreign savings abroad, and enviable redistribution to its citizens via a generous domestic welfare system that includes various mechanisms for transferring petro-rents to nationals, including the use of energy subsidies.

Despite historic economic advantages, Kuwait has been facing serious fiscal and economic challenges following the collapse of the oil price in mid-2014, which rendered the cutting of energy subsidies at an accelerated pace a policy priority for the government. In the wake of the rejection of various schemes and failed reform attempts, in March-April 2016 it was proposed that electricity prices for residential use by non-owner occupied residences (who are effectively expatriates) should increase from US $\$ 0.007$, progressively, to US $\$ 0.05 /$ kilowatt hour, and for commercial use from US $\$ 0.007$ to US $\$ 0.082 /$ kilowatt hour. For remaining users, the price stayed at US $\$ 0.007$, subsidized at a rate of approximately 95 per cent. Reforming gasoline prices uniformly was a more successful endeavour when, in August 2016, the government, circumventing parliament and raised gasoline prices by 41-83 per cent (differentiated by octane levels) to the international shadow price effective September 2016. Kuwait had been the last GCC state to reform its gasoline prices, at which point it had the lowest domestic gasoline prices globally, together with a US $\$ 15.3$ billion deficit for 2016 . Despite widespread opposition, which culminated in the parliament's failed attempt to reverse the price change in court, the government insisted its pricing reform would solve fiscal pressures, economic inefficiencies, and energy over-consumption, and that any subsequent inflation would be muted.

Kuwait has very liberal trade policies. The country signed the General Agreement on Tariffs and Trade in 1963 and has been a WTO member since 1995. Its trade balance in 2015 stood at 9.12 per cent of its GDP, while trade in services reached 26.18 per cent. While Kuwait's imports have been steadily increasing, its exports have been volatile (as Figure 2 shows), being subject to world demand fluctuations (for example, due to the global financial crisis in 2008) and volatile oil price movements.

Figure 2: Growth of Kuwaiti trade 2006-2017.

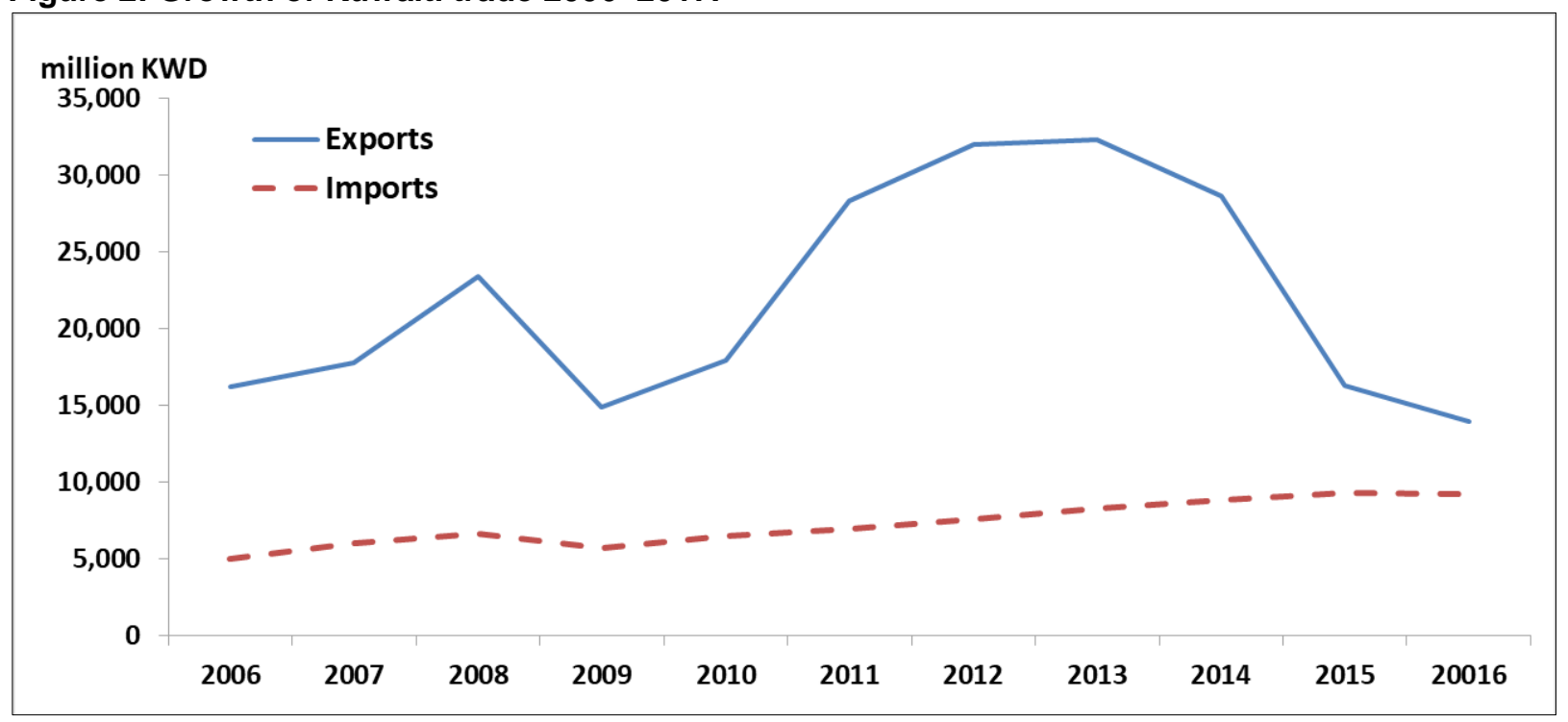

Source: Kuwait CSB Foreign Trade Statistics (2017b). 
Data on Kuwait's economic structure reveal dynamics pertinent to assessing the impacts of trade and pricing reforms. Key structural elements of the Kuwaiti economy are depicted in Table 1 using the database for 2013 (the most recently available) constructed to calibrate this paper's economy-wide model.

Table 1: Economic structural elements 2013

\begin{tabular}{lcccc}
\hline Sector/ Percentage & $\begin{array}{c}\text { Share of } \\
\text { GDPFC* }\end{array}$ & $\begin{array}{c}\text { Share of total } \\
\text { exports }\end{array}$ & $\begin{array}{c}\text { Export share of } \\
\text { output }\end{array}$ & $\begin{array}{c}\text { Net exports } \\
\text { over output }\end{array}$ \\
\hline $\mathbf{1}$ Agriculture & 0.3 & 0.0 & 1.3 & -63.3 \\
$\mathbf{2}$ Mining & 1.4 & 0.0 & 0.0 & 0.0 \\
$\mathbf{3}$ Crude oil & 48.9 & 42.1 & 50.5 & 50.3 \\
$\mathbf{4}$ Gas and petro-services & 0.9 & 1.3 & 50.5 & 50.3 \\
$\mathbf{5}$ Oil refining & 5.4 & 38.6 & 72.6 & 72.2 \\
$\mathbf{6}$ Chemical & 1.1 & 3.4 & 37.4 & -1.7 \\
$\mathbf{7}$ Light manufacturing & 0.8 & 0.4 & 4.1 & -56.0 \\
$\mathbf{8}$ Heavy manufacturing & 0.8 & 1.9 & 8.1 & -72.0 \\
$\mathbf{9}$ Electricity & 0.6 & 0.0 & 0.0 & 0.0 \\
$\mathbf{1 0}$ Other network services & 4.6 & 4.6 & 32.3 & 31.4 \\
$\mathbf{1 1}$ Construction & 2.2 & 0.0 & 0.0 & 0.0 \\
$\mathbf{1 2}$ Transport & 3.4 & 5.7 & 38.9 & 14.1 \\
$\mathbf{1 3}$ Financial services & 7.8 & 0.7 & 4.1 & -1.3 \\
$\mathbf{1 4}$ Other services & 21.7 & 1.2 & 1.8 & -15.6 \\
\hline
\end{tabular}

* GDPFC is GDP at factor cost, which is the sum of value added in each industry.

Source: Model database (social accounting matrix) constructed by author for 2013 .

After hydrocarbons (consisting of 'Crude oil, 'Gas and petro-services', and 'Oil refining'), 'Other services' are the second-highest value-adding industry, employing mostly expatriate labour. The 'Chemicals', 'Other network services', and 'Transport' industries generate 14 per cent of exports, each exporting approximately one-third of its output. Kuwait has some existing expandable non-oil exportation capacity as well as import-competing industries. The data point to a heavy indirect effect through imported intermediate inputs (which form a large part of all intermediates). This structure has two main consequences: first, the economy had a capital surplus, which was funnelled into investments abroad and foreign aid; and second, most of the consumer and intermediate consumption had to be met through imports. 
Figure 3 and Figure 4 summarize the industrial composition of Kuwait's non-hydrocarbon exports and imports during the period 2013-17, respectively. 
Figure 3: Kuwaiti non-hydrocarbon exports 2013-2017.

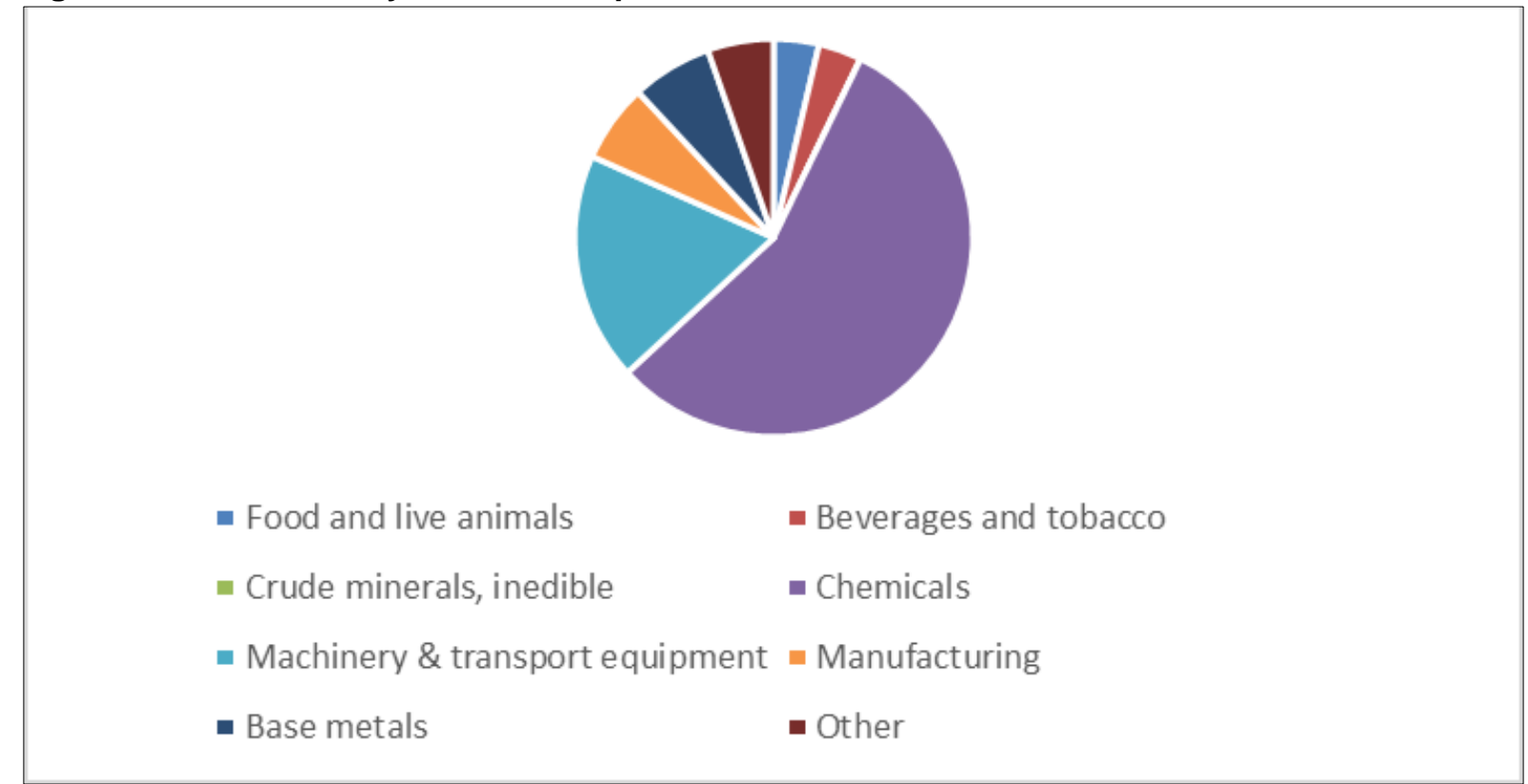

Source: Author's calculations based on data from Kuwait CSB Foreign Trade Statistics (2017b).

Figure 4: Kuwaiti imports 2013-2017.

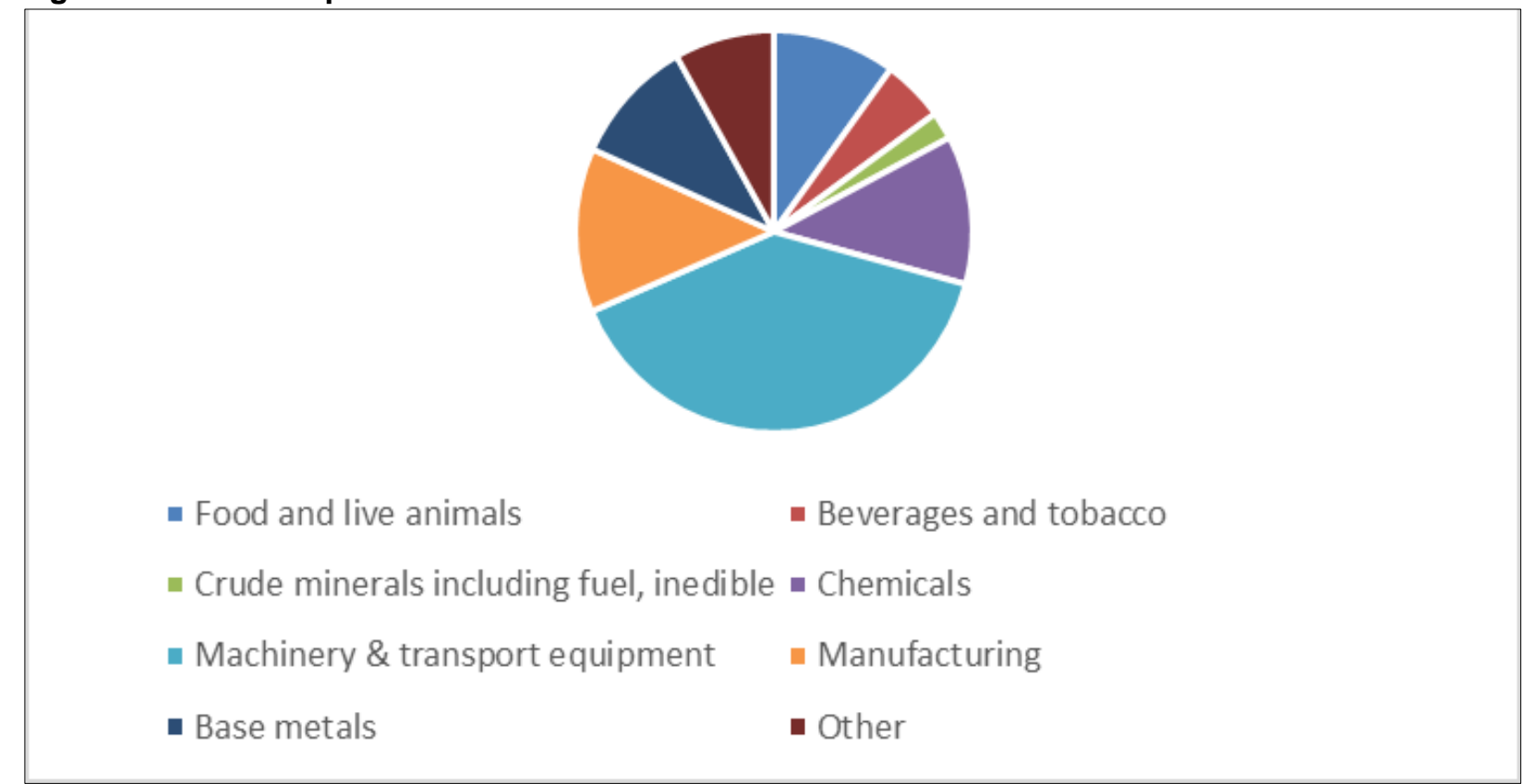

Source: Author's calculations based on data from Kuwait CSB Foreign Trade Statistics (2017b). 
Table 2: Comparative values of key non-hydrocarbon Kuwaiti exports and imports 2013- 2017

\begin{tabular}{lccccc}
\hline Value (million KWD) & $\mathbf{2 0 1 3}$ & $\mathbf{2 0 1 4}$ & $\mathbf{2 0 1 5}$ & $\mathbf{2 0 1 6}$ & $\mathbf{2 0 1 7}$ \\
\hline $\begin{array}{l}\text { Chemicals } \\
\quad \text { Exports }\end{array}$ & 1,034 & 920 & 819 & 671 & 722 \\
$\quad$ Imports & 994 & 1,177 & 1,144 & 1,136 & 1,331 \\
$\begin{array}{l}\text { Machinery \& transport equipment } \\
\quad \text { Exports }\end{array}$ & 343 & 413 & 401 & 325 & 404 \\
$\quad$ Imports & 3,266 & 3,399 & 3,618 & 3,623 & 3,997 \\
$\begin{array}{l}\text { Base metals } \\
\quad \text { Exports }\end{array}$ & & & & & \\
$\quad$ Imports & 121 & 116 & 70 & 69 & 84 \\
$\begin{array}{l}\text { Manufacturing } \\
\text { Exports }\end{array}$ & 842 & 825 & 817 & 1,003 & 1,075 \\
$\quad$ Imports & 118 & 130 & 128 & 114 & 104 \\
\hline Souce:Misty & 1,097 & 1,163 & 1,299 & 1,227 & 1,284 \\
\hline
\end{tabular}

Source: Ministry of Planning, Annual Statistics Abstract (2000), Statistics Abstract in 25 years (1990).

The 'Chemicals' sector (fertilizers, organic chemical, and rubber products, and others), contributes the lion's share of non-oil exports (see Table 2), followed by 'Machinery and transport equipment' (such as vehicle parts and mechanical appliances). The largest imports are in the 'Machinery and transport equipment' industry, followed by 'Manufacturing'.

Critical to trade is the existence of local non-oil import-competing industries in Kuwait, the expansion of which has been a key development target. To that end, the National Assembly approved US $\$ 103.4$ billion to fund more than 800 projects, with the aim of moving the country towards becoming a banking, trade, and services hub for the GCC and the MENA area by 2030. In March 2013, the government invested KWD2 billion in a fund dedicated to support small and medium enterprises and young entrepreneurs. Moreover, the fiscal savings achieved by the 2016 subsidy reform were proposed as a means of supporting diversification of non-oil exports. Nevertheless, non-oil exports (such as 'Chemicals' and 'Base metals') have only plummeted since key economic shocks (namely the oil price collapse in 2014 and energy pricing reform in 2016, see Table 3), confirming limited expansion capacity, despite depreciation of the real exchange rate. This challenge supports the assumption that energy subsidies had, indeed, offered an extra advantage to these industries in international trade.

Table 3. Value and composition of imports and exports 2013-2017

\begin{tabular}{lccccc}
\hline Value (million KWD) & $\mathbf{2 0 1 3}$ & $\mathbf{2 0 1 4}$ & $\mathbf{2 0 1 5}$ & $\mathbf{2 0 1 6}$ & $\mathbf{2 0 1 7}$ \\
\hline Exports & & & & & \\
Hydrocarbon products & 28,636 & 16,280 & 13,952 & 16,678 & 32,363 \\
Non-hydrocarbons products & 1,446 & 1,284 & 1,185 & 982 & 1,034 \\
Re-exports & 412 & 519 & 514 & 444 & 610 \\
Total & $\mathbf{3 2 , 3 6 3}$ & $\mathbf{2 8 , 6 3 6}$ & $\mathbf{1 6 , 2 8 0}$ & $\mathbf{1 3 , 9 5 2}$ & $\mathbf{1 6 , 6 7 8}$ \\
Imports & & & & & \\
Total & $\mathbf{8 , 3 0 9}$ & $\mathbf{8 , 8 2 9}$ & $\mathbf{9 , 3 1 6}$ & $\mathbf{9 , 2 6 9}$ & $\mathbf{1 0 , 1 8 3}$ \\
\hline
\end{tabular}

Source: Kuwait Central Statistical Bureau (CSB) Foreign Trade Statistics (2017b).

Non-oil productive capacity is limited and hydrocarbons continue to dominate trade. 


\subsection{Key economic features}

\section{Structural rigidities}

In addition to high levels of specialization in hydrocarbons and its dominance over trade (as described in Section 2.1), Kuwait's economy is constrained by other structural rigidities. The public sector dominates the economy - which extends to the nominally independent but publicly owned hydrocarbon industry. In 2014, the public sector generated over 65 per cent of GDP, compared with a private sector share that has ranged between 21 per cent (1989) and 41 per cent (2010). Furthermore, despite privatization efforts, Kuwait's private sector is small, and the public sector continues to dominate the economy in various industries, including petroleum. Kuwait's vision for 2035, detailed in its Development Plan 2010-2014, has centred on liberal trade, with the aim of improving the country's business environment, increasing the productivity growth of the non-energy sectors, and increasing the participation of the private sector (local and foreign) in the economy from its current low level of about 25 per cent. The public sector is committed to two-thirds of total capital formation and is also the employer of choice for Kuwaiti workers (it employs the majority of them) and they in turn form the majority of public sector employees.

These structural rigidities have contributed to fiscal rigidities, described below.

\section{Fiscal rigidities, subsidies, and taxes}

As the oil price collapsed from US $\$ 103 /$ barrel (bl) in January 2014 to US $\$ 30 / b l$ in January 2016 , the extent of fiscal rigidities challenging the economy were exposed, as official figures anticipate a further budget deficit of US\$73 billion over 2016-2019 ('Wazīr al-Māliyya', 2016).

Adjusting the fiscal gap between revenue and expenditure is difficult during periods of low oil prices due to the following factors. The first factor is the country's negligible tax revenue. Kuwait applies negligible rates on labour and corporate income (Shehabi (2017) offers details). As part of fiscal reforms in 2016, the government approved the introduction of corporate taxes of 10 per cent on the profits of Kuwaiti firms and multinationals' permanent establishments (Al-Sennari, 2016). A value-added tax (VAT) of 5 per cent is expected to be imposed in 2018, in line with a GCC-wide agreement. As another means of diversifying government revenue, in 2017 parliament proposed the imposition of a 5 per cent tax on foreign remittances, which equalled 5 per cent of GDP and 18 per cent of government revenue in 2015 (with estimates as high as 35 per cent in 2016) (Farouq \& Mousa, 2017) but this is yet to be implemented.

The second factor is the large size of current expenditure, which constitutes 80 per cent of government expenditure, and half of which funds the public sector wage bill. In 2014, transfers and subsidies to households and firms represented more than half of the government's total spending. Such large commitments have reduced the scope and flexibility of other public expenditures, which are rigid given political opposition to any reduction of public transfers.

The third factor contributing to fiscal rigidities is the large fiscal commitments which form part of Kuwait's welfare transfers; ${ }^{3}$ these include pervasive and conspicuously high energy subsidies, even in comparison to other petrostates. Per the Social Accounting Matrix (SAM) data, the reported consumption subsidies represent approximately 8 per cent of value-added activities. Their value, combined with government-reported industry subsidies in 2013 , was US $\$ 8,670$ million. In 2015 , Kuwait had the fifth-highest subsidization rate on energy products (when comparing domestic prices with their international shadow prices); it was estimated at 70 per cent, ${ }^{4}$ as 

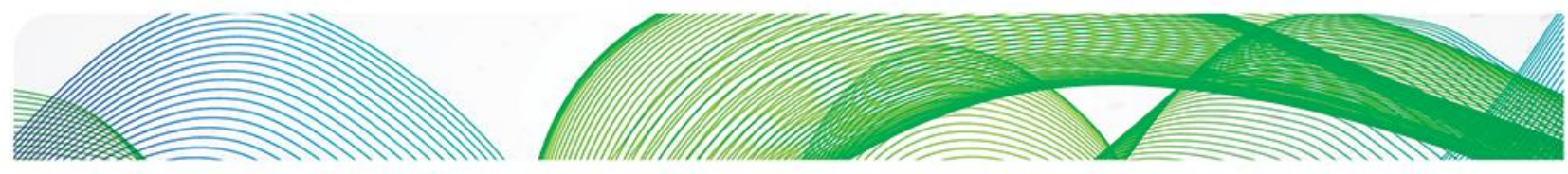

\section{ON
तN}

Figure 5 shows. 

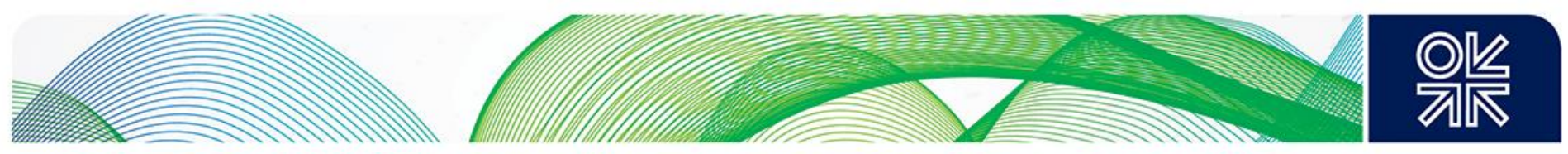

Figure 5: Average subsidization rates for 2015.

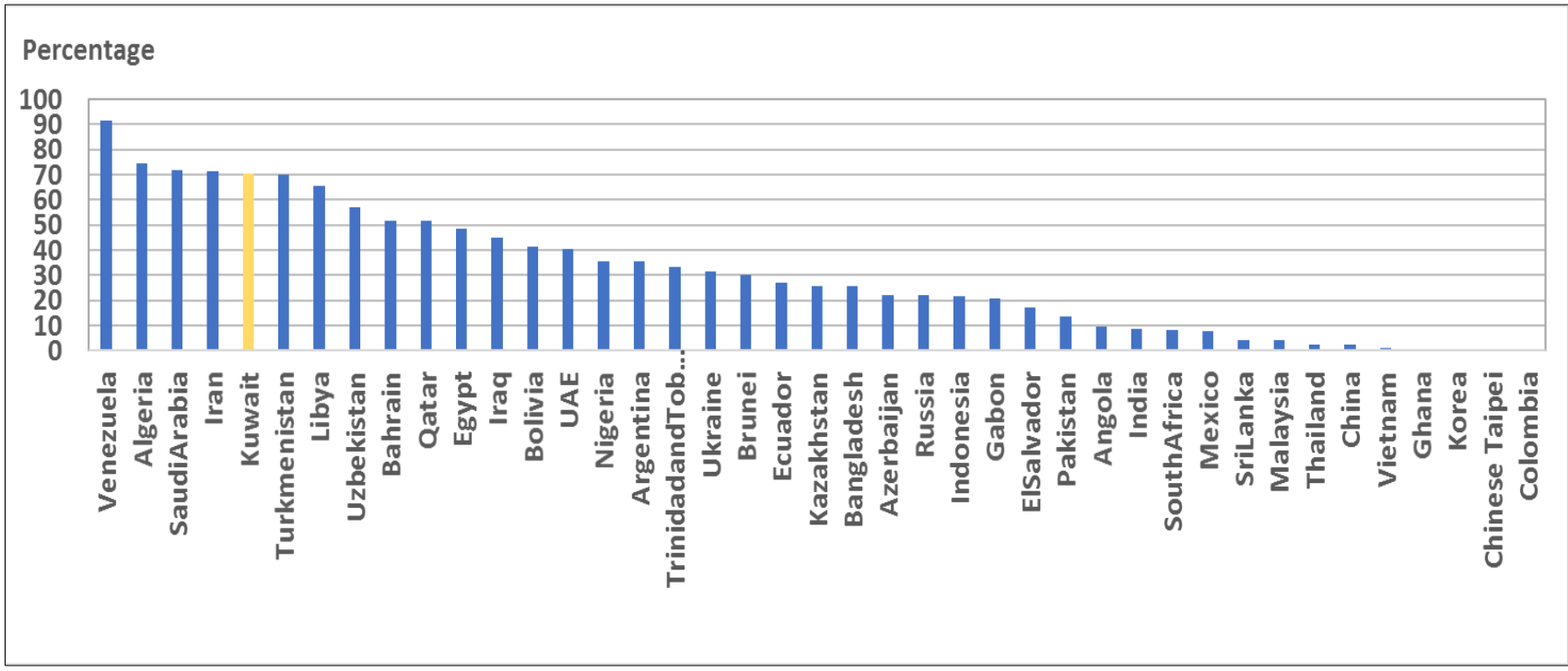

Source: Author's work using EIA (2017) data.

Up to mid-2016, Kuwaiti electricity prices were less than one twentieth of generation costs and had not changed since 1990 (Shehabi, 2017). Water, for which the desalination techniques in use are mostly based on local hydrocarbon resources, has been offered at virtually no cost. Kuwait was one of the last countries to reform local energy prices, in August 2016, before which local gasoline prices had been among the lowest in the world. By 2014, Kuwait was the world's sixth-highest per capita energy consumer (World Bank, 2017), with domestic consumption having steadily increased over the previous 25 years. Given the large domestic energy requirements for consumption, reconstruction, private consumption, and desalination, these subsidies countervail attempts to restore fiscal balance. Figure 6 demonstrates the resulting fiscal pressures by comparing declining oil (and correspondingly government) revenues with increasing welfare and subsidy expenditures. 
Figure 6: Subsidies in Kuwait and petroleum export revenue.

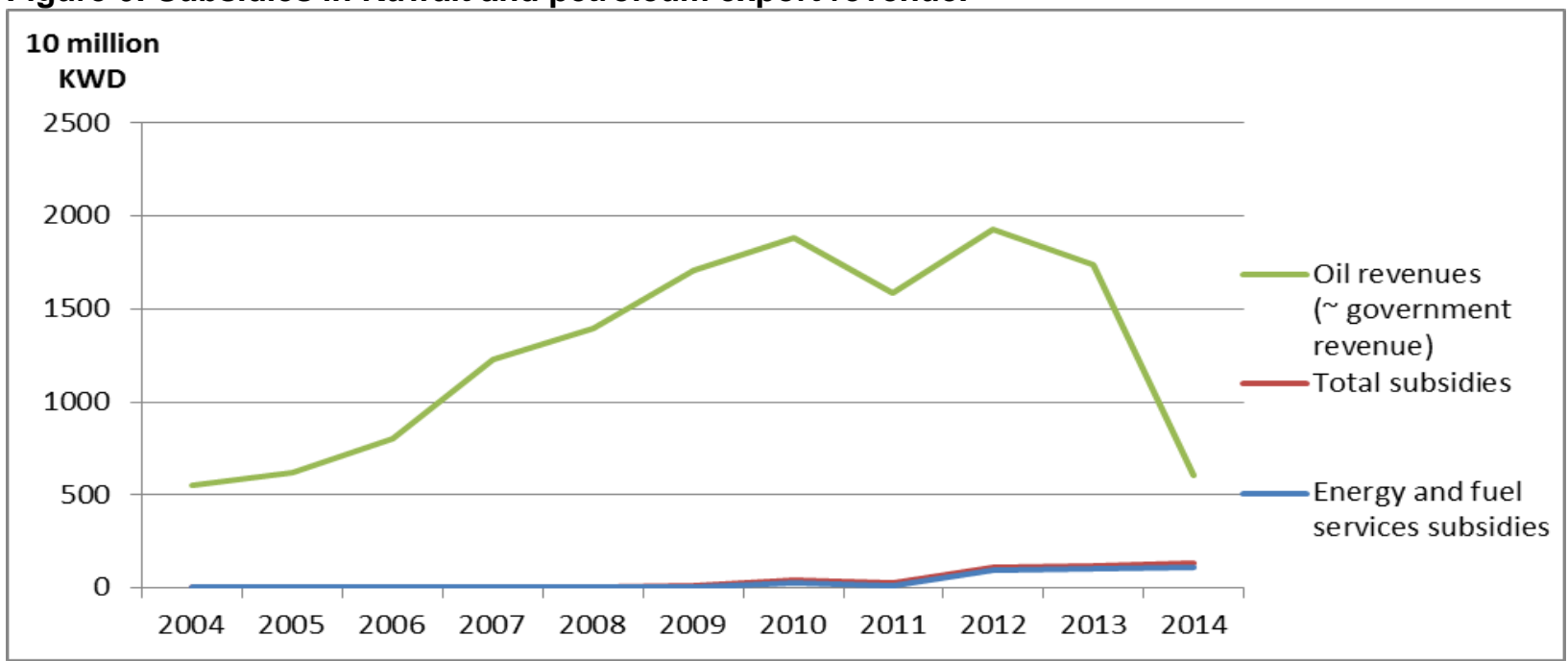

Source: Author's analysis using data from the Kuwait Government Finance Statistics - Ministry of Planning.

\section{Expatriate labour}

The structure of the labour force in Kuwait is unique, and has ensuing sectoral, wage, and labour mobility implications. There are effectively two separate labour markets. Expatriates comprise 83 per cent of Kuwait's labour force (Public Authority for Civil Information, 2018), the majority of whom are employed in the private sector at lower wages, with flexible labour contracts linked to employers through a strict system of employer-sponsorship of expatriate labour named kafāla. Overall, 77 per cent of Kuwaitis are employed by the bloated public sector, including the subsidized government-owned energy industries which employ mostly Kuwaitis. Public sector positions prioritize indigenous employment and offer salaries exceeding those in the private sector for similar levels of education and technical training (Al-Kaisi, 1993).

\section{Kuwait Investment Authority (KIA)}

Importantly, the KIA is an important institutional and financial feature of the Kuwaiti economy, acting as a financing alternative to oil revenue shortages and as a means of smoothing out short-run governmental expenditures during deficits. It manages two funds: the FGF, which is a long-term intergenerational fund established as an alternative source of government revenue to oil; and the GRF, which serves a macro-stabilization objective, offering fiscal rebalancing through flows to and from the fund. Kuwait acquired a substantial and diversified international asset portfolio, which the SWF Institute estimated at US $\$ 524$ billion (SWF, n.d.), more than three times the size of Kuwait's record-high GDP in 2013 and more than five times the country's export revenue in that year. As such, flows to and from the KIA are an important feature to model. 
Figure 7: Cumulative Kuwaiti firm shares of industry.

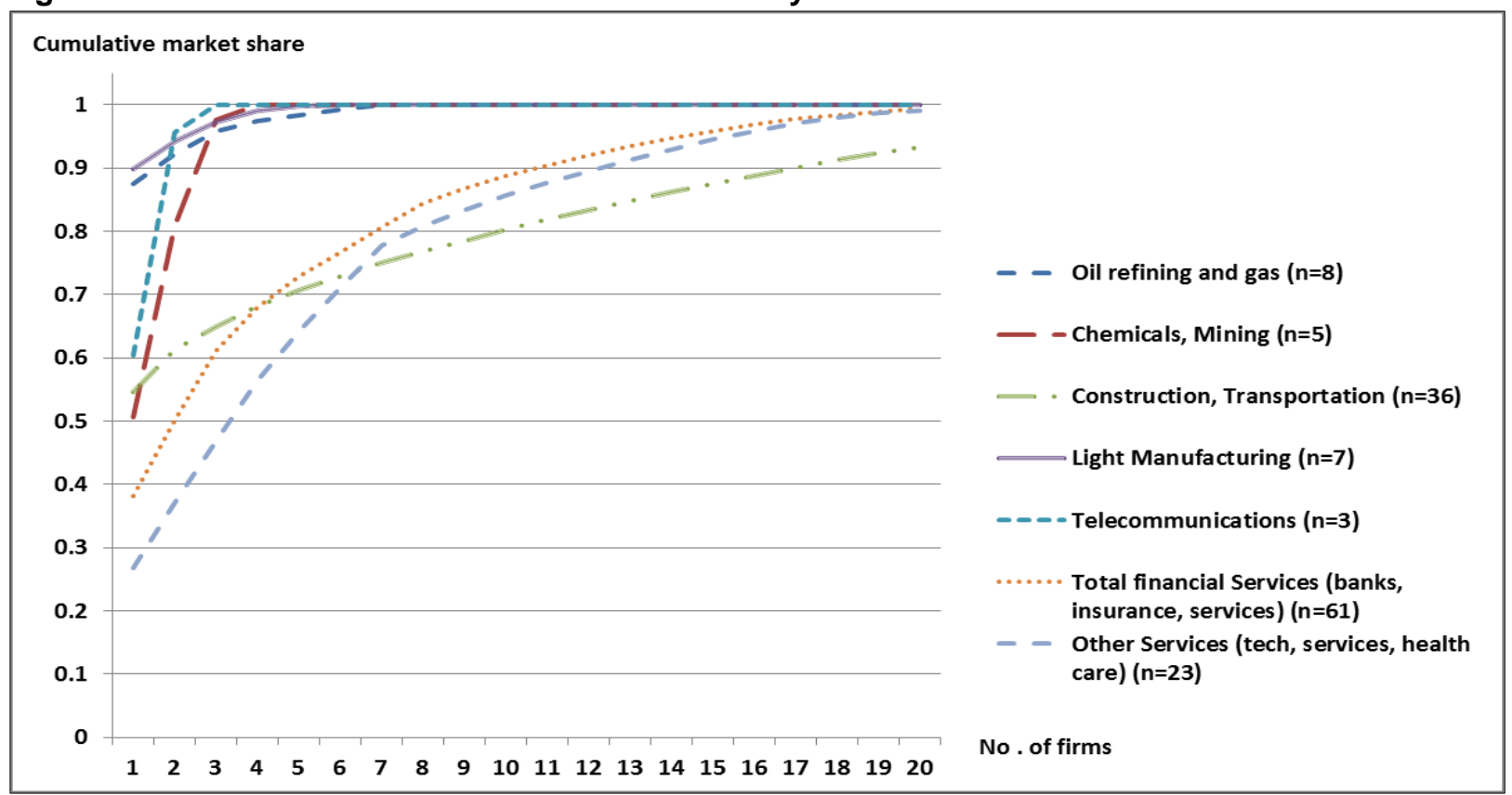

Note: Shares are calculated based on total industry revenue data, except for financial services which are calculated based on net profit (due to the lack of revenue data). The vertical axis shows the cumulative share, and the horizontal axis shows the number of total firms $n$.

Source: Author's analysis using data from the Kuwaiti Stock Exchange (2013).

\section{Oligopoly}

The economy is dominated by oligopolistic firms (see Figure 7), led by members of the politically influential merchant elite. Shehabi (2017) examines firm- and industry-level market capitalization and revenue data, to reveal that oligopolies are pervasive in Kuwait. This pervasiveness is evidenced by the high concentration of industries' capital and revenue levels within a few companies across all industries. It is not surprising that a combination of the large scale required to achieve minimum efficiency in modern technology, together with the small scale of Kuwait (and similar GCC economies), should lead to the emergence of oligopolies or monopolized industries, particularly in protected services. While it is natural for all economies to have oligopolies, short-run oligopoly rent is destroyed in the long run by competition-induced innovation (Schumpeter 1942; Aghion \& Howitt, 1992). This is problematic to the extent that oligopolies distort markets and prices and their sustained rents engender strategic behaviours that detract from growth-enhancing innovation. Importantly to Kuwait and other small economies with similarly high levels of specialization, oligopolies exhibit distortionary behaviour that is exacerbated by high subsidies, because subsidizing the negatively impacted industries enables them to be profitable at their existing levels of investments and innovation, thus reducing their economic incentives to expand. Government-dominated industries are, by definition, monopolies and oligopolies in the economy. The government has adopted plans to increase industrial competitiveness and expand the private sector. Yet reforms attempts have had limited success, largely due to strong public discontent and parliamentary obstruction. 


\section{Modelling subsidies and trade}

This model builds upon much of the work done in Shehabi (2017), which builds on Asano and Tyers (2015) which represent oligopoly behaviour and its regulation explicitly.

\subsection{Genesis}

The model incorporates core features of conventional economy-wide modelling. The 'almost small' characterization of the modelled economy follows Harris (1984) and Dixon et al. (1982) and its openness extends to financial markets via endogenous saving and investment and open capital and current accounts. These assumptions are essential in the case of Kuwait, which has a small economy that is highly dependent on trade (including imports in markets where it is a price taker) and on international financial flows. Like that of Balistreri and Markusen (2009), the model includes the standard Armington ${ }^{5}$ constant elasticity of substitution (CES) nesting structures that imply product differentiation between home and foreign products. Similar differentiation applies between common home products supplied by oligopolistic firms, though elasticities of substitution are larger in this case.

Financial flows and real exchange rate changes are endogenous, while external economic conditions, such as yields on investments abroad and global oil market trends, are exogenous and can be shocked in model simulations. The real exchange rate represents the common currency ratio of the home price of a bundle of (traded and non-traded) goods and services at home relative to that abroad, and is modelled accordingly. Therefore, it is sensitive to both the performance of the traded industries and to that of the non-traded services sector. The model adopts neoclassical features in characterizing consumption preferences and the variable costs of production, including the optimization of representative agent behaviour, full input substitutability, and flexible product and factor prices.

The model, however, breaks away from existing and traditional frameworks through its representation of oligopoly behaviour and in extensions to the model, as detailed in Shehabi (2017). In assessing efficiency and economic policy, the omission of oligopoly from existing models of small economies like Kuwait is particularly important, since the assumption that policies directed to the advantage of one industry will not create rents that affect others is indefensible. It is well understood that competition induces innovation, so that short-run oligopoly rent is destroyed in the long run by innovation (Schumpeter 1911, 1942). ${ }^{6}$ This idea has become central to modern research on economic growth (Segerstrom, Anant, \& Dinopoulos, 1990; Aghion \& Howitt, 1992; Aghion, Akcigit, \& Howitt, 2013). Oligopolies distort markets and prices while their sustained rents engender strategic behaviours that detract from growth-enhancing innovation (Grossman \& Helpman, 2014). Devarajan and Rodrik (1991), in one of the first attempts to incorporate oligopoly behaviour in a CGE framework, suggest that procompetitive forces operating on oligopolistic firms can influence the magnitude of efficiency gains resulting from trade liberalization in Cameroon. Incorporation of oligopoly behaviour by Tyers (2015) suggests that the full exploitation of oligopoly market power in Australia would cause a reduction of real GDP by as much as a third in the long run. Of course, in advanced economies, this effect is moderated by pricing surveillance and price-cap regulation. Yet in resource exporters, oligopolies play an additional role: their increased rents during booms and their (usually subsidized) losses during busts further impair economic performance. The model of Shehabi (2017) was the first to consider the role of oligopoly and the resulting efficiency, in the context of economies in Kuwait and the MENA region.

\subsection{Model structure}

Two regions (Kuwait and the Rest of the World) are incorporated in a comparative static framework, employing different closures to mimic the economy's long run responses to external or policy shocks.

\footnotetext{
${ }^{5}$ According to Armington's (1969) theory, home and foreign goods (imports) are imperfect substitutes in the aggregate production of a given industry. Thus, tariff reduction or exchange rate appreciations will make home goods relatively less expensive, thus shifting the composition of the aggregate output towards imports. The Armington specification in the model allows the economy to produce, import, and export products with the same sectoral classification.

6 The core idea is 'creative destruction', which entails the concept that innovation is induced by competitive forces and that, while any single innovation confers rents in the short run, subsequent competitive innovations 'destroy' these rents, maintaining efficiency (Schumpeter, 1942: 82-83).
} 
The model represents specifically external financial flows, domestic fiscal policy, oligopolistic industrial structures, government regulation, labour market composition by skill level and nationality source, and oil prices. All in all, there are 3,820 components representing 247 equation blocks, with 3,606 separate endogenous variables, implemented using the GEMPACK (General Equilibrium Modelling PACKage) software. The following offers an overview of the salient parts of the model, with additional model details confined to Appendix A.

As modelled, the Kuwaiti economy has one representative household that consumes home produced and imported goods, supplies indigenous and expatriate labour and skill, and owns physical capital. The model has macroeconomic elements, including endogenous saving and investment, open capital and current accounts, and a complete system of taxes and subsidies. Financial flows and real exchange rate changes are endogenous and external economic conditions (as represented by bond yields and commodity prices) are readily shocked as part of analytical applications.

\section{Demand}

On the demand side, firms in 14 industries rent capital and hire workers, supplying products and services to meet five sources of demand: final, intermediate, investment, government, and foreign demands. The model makes conventional assumptions about the consumption of home products in each sector, whereby domestic products are differentiated by variety via CES nests. These local products are further differentiated from imported foreign varieties. Accordingly, firms in a given industry monopolize the domestic market for their individual product variety, which is differentiated both from imported varieties and other home-produced ones. As oligopolists or monopolists, firms' optimal sale price depends on the varietal elasticity of demand they face $\left(\varepsilon_{i}\right)$ via the Lerner formula. This elasticity of collective demand is then a weighted average of the elasticities of demand in the five markets it supplies (see above):

$\varepsilon_{i}=S_{i}^{F} \varepsilon_{i}^{F}+S_{i}^{G} \varepsilon_{i}^{G}+S_{i}^{I} \varepsilon_{i}^{I}+S_{i}^{T} \varepsilon_{i}^{T}+S_{i}^{X} \varepsilon_{i}^{X} \quad \forall i$,

where $\left(\varepsilon_{i}^{X}<\varepsilon_{i}^{F}<\varepsilon_{i}^{G}<\varepsilon_{i}^{I}<\varepsilon_{i}^{T}<0\right)$

and the following subscripts represent the following demand sources: $F$ represents final, $I$ intermediate, $T$ investment, $G$ government, and $X$ foreign demands; while $S_{i}^{j}$ denotes the fully endogenous volume share of the home product in market $j$ for each source of demand $j$.

Each of these demand elasticities depends on component elasticities of substitution, firm numbers, conjectural variation parameters in industry $i$ (reprsented by $\mu_{i}$ ) that indicate the extent of collusion in price setting, and further sets of shares. The conjectural variations parameters in each indicate the influence of pricing choices by any individual firm on the price set by other firms in the industry. These relationships are complex and Shehabi (2017) details their analytics. Yet relevant to trade, being the central subject of this paper, final demand and intermediate demand elasticities are important and are detailed in the Appendix.

The aggregate household's expenditure function is used to derive the consumer price index (CPI), which is a Cobb-Douglas-CES index of after-tax prices of both home products and imports. Collective utility is also defined as a Cobb-Douglas combination of consumption volumes by generic products, so CPI-deflated GNP is a measure of overall economic welfare.

\section{Supply side and oligopolies}

The production technology is Cobb-Douglas in variable factors and intermediate inputs, the latter being composites (CES nests) of home and imported products and services. The model captures key Kuwaiti oligopolistic (and monopolistic) industries and targeted regulatory surveillance, a key economic feature (Section 2.2), as follows.

Uniquely, in a departure from conventional CGE modelling, the model represents oligopoly with behavioural structure from Shehabi (2017), based on Asano and Tyers (2015), which is based on earlier work done by Tyers (2015), Gunasekera and Tyers (1990), Harris (1984), Horridge (1987), and Tyers (2005), and is similar to that of Devarajan \& Rodrik (1991). It assumes that firms in all economic sectors, private and state-owned firms, are oligopolistic in their product pricing behaviour, operate in 
differentiated product markets, and adopt profit maximizing rules, with each carrying fixed capital and labour costs that can lead to the potential for unrealized economies of scale and to the occurrence of pure (economic) profits (or losses) at market levels. This representation emphasizes oligopoly rents in the spirit of Blanchard and Giavazzi (2003) who, in a closed-economy general equilibrium setting, found that increased competition is beneficial to an economy because it leads firms to lower their markups, in turn lowering prices and increasing output and exports economy wide.

Oligopolistic firms operate in differentiated product markets. As such, each firm exploits its monopoly over the supply of its own product variety through selecting the price, and therefore its markup, that maximizes its profit. Within a given industry (economic sector), each firm faces an elasticity of demand that depends on the individual elasticities of the various demand sources and also on the number of other firms and the degree of pricing collusion between them. Symmetry within each economic sector implies a common optimal unregulated markup for each firm. Oligopolistic firms set their price $p_{i}$ relative to average variable cost $v_{i}$ so as to maximize profit by applying the Lerner markup formula:

$m_{i}=\frac{p_{i}}{v_{i}}=\frac{1}{1+\frac{1}{\varepsilon_{i}}} \quad \forall i$

In (2), $m_{i}$ is the markup. All firms in all economic activities have oligopoly power in product and input markets. ${ }^{7}$ Larger firms are subject to pricing surveillance regulation. The model calculates pure or economic profits or losses by firms as revenue net of fixed and variable costs.

Firms collude on prices to varying extents. Collusion is represented through calibrated conjectural variation parameters $\left(\mu_{i}\right)$, which are critical because they capture the degree of price-setting collusion that occurs between the firms in a given industry. Oligopolistic firms operate in differentiated product markets.

Incorporating imperfect competition requires additional data to calibrate the model and renders the calibration process more complex. In order to incorporate into the model the realistic feature that larger firms are subject to regulation and pricing surveillance, data ${ }^{8}$ are analysed on industry structure, conduct, and performance to determine cost and pricing behaviour, represented in the model through parameterization. Importantly, collusion and other values can be set to represent a degree of regulatory surveillance or price cap enforcement by the Kuwaiti Competition Protection Authority.

\section{Factors of production and input demands}

The model has seven primary factors of production: physical capital, Kuwaiti unskilled labour, Kuwaiti skilled labour, expatriate unskilled labour, expatriate skilled labour, arable land, and natural resources. Solving the firm's cost minimization problem with Cobb-Douglas technology in variable factors and inputs yields the volumes of each intermediate demand. Unit input demands are Leontief input-output coefficients, but they are not fixed in this model. Their values are determined by substitution behaviour (between domestic and imported inputs) in response to product and input prices.

To capture the labour market, the model expands industries' production functions to include four labour types that are differentiated by nationality and skill. To reflect the Kuwaiti labour market's segmentation, wage and mobility rigidities in the labour market are assumed, especially those pertaining to public sector employment and low-skill wages. Employment contracts are flexible for expatriates.

\section{Government}

Fiscal rigidities are included in the model through a full representation of government accounts and macroeconomic elements, including endogenous saving and investment, open capital and current accounts, and a complete system of expanded consumption subsidies and of taxes-both from direct taxes (on capital, labour income, land, and resource rents) and from indirect taxes (on trade and 
consumption expenditures). The government transfer variable is therefore exploited beyond the applications by Asano and Tyers (2015) by not setting government transfers constant relative to the consumer price level. While the fiscal deficit remains endogenous, the government saving varies, driving the current account deficit.

To represent Kuwait's public sector dominance and fiscal rigidities, given that KPC and the electricity company operate as large and nominally independent corporations, they are represented as separate monopoly firms with their own factor demand and output. The government is treated as the residual owner of additional rent payments (profits) after payments to fixed and variable capital and labour. The collection of oil export revenue appears as a quasi-tax payment, used to infer a corporate tax rate. Subsidies are represented by negative consumption and company taxes. Although Kuwait has negligible income tax rates, with some of these government revenue sources being inactive, the modelling includes them by identifying minimal values for income taxes in the SAM to enable the simulation of alternative tax policy options and the analysis of potential taxation reforms.

\section{Consumption subsidy}

This model differentiates consumption subsidy by industry. Artificial reductions in local prices below firms' output prices are captured as consumption subsidies to households. Consumption subsidies are applied at a uniform rate of $\tau_{i}^{C}<0$ on household final demand, approximated as the quotient of consumption subsidy expense provided to the household and their consumption value base. Thus, the total final consumption subsidy cost to the government is:

$T_{C}=\sum_{i=1}^{N} \tau_{i}^{C} p_{i} D_{i}+\sum_{i=1}^{N} \tau_{i}^{C} p_{i}^{*} M_{i}$,

where $D_{i}$ is the local final demand of home goods in industry $i$; $M_{i}$ is the local final demand of imported goods; $I_{i}$ is the industry input of home produced goods; $I_{i}^{*}$ is the industry input of imported products; $p_{i}$ is the domestic price of home-produced goods; $p_{i}^{*}$ is the domestic price of imported goods; and $\tau_{i}^{C}$ is the industry-specific ad valorem consumption tax rate for the products of industry $i$. Corporate subsidies (both reported and calculated on intermediate purchases) are accounted for against total taxes paid by each industry to arrive at a net corporate tax rate $\tau_{i}^{K}$. Initially, highly subsidized industries like electricity have a net large negative tax rate.

\section{Savings, financial flows, and the KIA}

The household savings rate is fixed, and firms retain net earnings at corporate savings rates that are also fixed and industry-specific. ${ }^{9}$ The model represents financial agents who manage portfolios of domestic and foreign assets, impacting the inflow and outflow of financial investments. The model also takes into account Kuwait's external financial flows, primarily flows to and from the KIA. These mimic, to the extent possible, the KIA's role as a source of government funds following oil price shocks. Both KIA funds are represented as receiving payments from the government directly, rather than from the oil sector, but withdrawals are allowed in the form of government borrowing. The model represents funds as being available for withdrawal from abroad through KIA at a different rate, which represents the rate of return otherwise earned by these funds and, therefore, the opportunity cost of the use of funds for fiscal balancing. ${ }^{10}$ To represent capital movement, home assets are differentiated from foreign assets and they also offer different yields, so that private finance flows across the border following departures from interest parity.

\subsection{Long-run macroeconomic behaviour}

The long-run version of the model is naturally Walrasian in that prices and interest rates all adjust to ensure that product, factor, and financial markets all clear. External flows are constrained by the balance

\footnotetext{
${ }^{9}$ Financial capital, whether domestically or foreign owned, can flow into the economy in the long run. There is no endogenous distinction between FDI as greenfield investment or acquisition.

${ }^{10}$ While in reality the macro-stabilization fund is the intended source for such withdrawals, the model does not distinguish between KIA funds; this reflects the lack of publicly available information about the composition and withdrawal practices of $\mathrm{KIA}$.
} 
of payments (which is implied by domestic agents satisfying their budget constraints), which drives adjustments in the real exchange rate in response to shocks. The total capital stock of the economy is endogenous, as is the level of capital use in each industry.

The open economy capital market has a market clearing identity that accounts for inward and outward financial flows. Inward and outward financial flows follow changes in interest rate parity, being the difference between the home and foreign real bond yields and expectations of the real exchange rate. In accordance with realistic changes in the long-run capital use within an economy, and consistent with Kuwait's considerable external holdings, the model's long-run closures allow changes through investment flows. Capital flows are set at the level where post-tax rates of return at home equal rates internationally, while also allowing firms to generate rents consistent with oligopoly behaviour. Therefore, the capital use level equates post-tax capital rate of return to post-tax 'market' returns, net of pure profits. Drops in taxation rates of capital income (or conversely, increases in subsidies) will cause the pre-tax rate of return demanded at home to drop and capital use to, correspondingly, increase. Important to the analysis, changes in real income levels at home impact long-run accumulations of home-owned capital.

\subsection{Closures}

Closures represent assumptions relating to which variables are free to change in response to shocks and also to which variables can adjust, reflecting policy targets and market clearance assumptions. While comparative static, the model employs difference closures to represent the responses of the Kuwaiti economy in both the short and long runs. These closures have four sub-closures reflecting four elements, namely: the labour market; fiscal closures; the financial capital market; and a market structure (oligopoly) sub-closure.

In this application to Kuwait, closures are one way in which the unique Kuwaiti economic features (detailed in Section 2.2) are captured in the model. They are as follows: the standard labour closure fixes the employment of Kuwaiti labour and enables endogenous movement of both skilled and unskilled expatriates. The real expatriate skilled and unskilled production wage rates (relative to an index of producer prices) are held fixed, while the real Kuwaiti skilled and unskilled production wages are endogenous. This closure is set in this way, first, to represent the inflexibility of the majority of Kuwaiti workers, who are likely to remain employed in the public sector, yet are sectorally mobile. Second, it accounts for the long-run flexibility of expatriate worker contracts, given that the stock of expatriate workers can fall with a decline in labour demand in both the short and long runs.

To represent more realistically the changes in either the fiscal deficit and/or transfer payments, the adopted fiscal closure has an endogenous fiscal deficit and welfare payments, with exogenous government spending on goods and services, and exogenous consumption subsidy rate and corporate tax rates (both of which are shocked). The capital market closures are discussed above. In the long run, the capital stock of the entire economy is mobile, so it adjusts (rises or falls) to maintain a fixed rate of return in all industries, with implications for financial flows on the balance of payments. Payments to the KIA, and withdrawals from it, remain endogenous in the model. Finally, the oligopoly sub-closure in the long run allows free entry and exit of firms at a given profitability level.

\subsection{Representation of broad economic structure}

CGE models require the use of an appropriate database that depicts all agents in an economy as well as the transactions among them within a given time period. An ideal framework is the Social Accounting Matrix (SAM), which extends input-output models to organize and consistently display the transactions as a circular flow of an economy's incomes and expenditures. It is a matrix presentation of the combined national income and product account, government accounts, and balance of payments accounts, as well as the country's input-output table.

Key elements of the SAM are presented in Section 2 above. Crucial to interpreting the results are the factor shares of value added in each industry, shown in Table 4. 
Table 4: Factor intensity in value added per industry 2013

\begin{tabular}{lccccccc}
\hline $\begin{array}{l}\text { Industry/ } \\
\text { Percentage }\end{array}$ & $\begin{array}{c}\text { Physical } \\
\text { capital }\end{array}$ & $\begin{array}{c}\text { Kuwaiti } \\
\text { unskilled } \\
\text { labour }\end{array}$ & $\begin{array}{c}\text { Kuwaiti } \\
\text { skilled } \\
\text { labour }\end{array}$ & $\begin{array}{c}\text { Expatriate } \\
\text { unskilled } \\
\text { labour }\end{array}$ & $\begin{array}{c}\text { Expatriate } \\
\text { skilled } \\
\text { labour }\end{array}$ & $\begin{array}{c}\text { Arable } \\
\text { land }\end{array}$ & $\begin{array}{c}\text { Natural } \\
\text { resources }\end{array}$ \\
\hline 1 Agriculture & 35.1 & 0.5 & 0.4 & 5.7 & 2.4 & 41.4 & 14.5 \\
2 Mining & 9.3 & 12.8 & 29.8 & 2.8 & 1.9 & 1.1 & 42.3 \\
3 Crude oil & 13.1 & 4.2 & 9.9 & 0.4 & 0.3 & 0.1 & 72.0 \\
4 Gas and petro- & & & & & & & \\
services & 25.7 & 15.1 & 18.4 & 1.1 & 0.7 & 0.1 & 39.0 \\
5 Oil refining & 86.6 & 5.4 & 6.6 & 0.8 & 0.5 & 0.0 & 0.0 \\
6 Chemical & 76.8 & 4.1 & 4.1 & 9.5 & 5.6 & 0.0 & 0.0 \\
7 Light manufacturing & 55.4 & 10.0 & 10.0 & 18.4 & 6.1 & 0.0 & 0.0 \\
8 Heavy & & & & & & & \\
manufacturing & 52.6 & 10.7 & 10.7 & 19.6 & 6.5 & 0.0 & 0.0 \\
9 Electricity & 86.1 & 7.6 & 4.9 & 0.8 & 0.5 & 0.0 & 0.0 \\
10 Other network & & & & & & & \\
services & 65.4 & 6.9 & 4.2 & 4.4 & 3.0 & 16.1 & 0.0 \\
11 Construction & 32.2 & 9.5 & 4.1 & 38.0 & 16.3 & 0.0 & 0.0 \\
12 Transport & 52.9 & 10.6 & 3.5 & 28.0 & 4.9 & 0.0 & 0.0 \\
13 Financial services & 31.2 & 8.3 & 19.3 & 14.5 & 26.8 & 0.0 & 0.0 \\
14 Other services & 17.0 & 1.7 & 14.9 & 41.8 & 24.6 & 0.0 & 0.0 \\
\hline
\end{tabular}

Source: Author's CGE model database (SAM) constructed for 2013.

'Oil refining', 'Electricity', 'Chemicals', and 'Other network services' have the highest capital intensity. The tradable Manufacturing industries ('Light' and 'Heavy') and the non-tradable 'Other services' and 'Construction' have the highest labour intensity. These relative intensities determine changes in factor rewards following commodity price shocks, thereby driving factor relocation and output across industries.

\section{Policy experiments}

The paper undertakes three experiments analysed in the long term only, due to the nature of subsidy reform which has long-term rather than transitory effects:

a. The first experiment concerns a decline in the energy subsidy rate in a high oil price environment without change in any policy instruments (Scenario 1);

b. The second experiment combines the first shock in experiment (a) with a decline in the oil price (this is similar to the position in Kuwait following the implementation of energy pricing reform in August 2016, whereby local energy prices were raised to match the international shadow price) (Scenario 2);

c. The last experiment combines both the shocks in (b) with a hypothetical microeconomic policy reform that includes competition policy and productivity boosts (Scenario 3).

Below is the pertinent summary of the results.

\subsection{Scenario 1: energy subsidy reform in a high oil price environment allowing adjustments in fiscal deficit and welfare payments}

To examine whether energy subsidies, including production subsidies, offer non-energy Kuwaiti industries an advantage in the international market, this counterfactual simulation examines the impact of reducing oil subsidies by 50 per cent to match the international shadow price of oil in Kuwait during the episodes of high oil prices, without any changes in other policy instruments. The shock is administered through a 50 per cent decrease in households' consumption subsidy rate on crude oil and 
refined oil products and a 5 per cent decrease in the corporate subsidy (and tax) rate (showing effectively as an increase of 5 per cent in the net corporate tax rate) on non-petroleum industries, calculated based on a pro rata basis. The adopted capital market and market structure closure, summarized in Section 3.4 above, dictate the length of run. Government expenditures on goods and services are assumed to remain constant. Table 5 column (a) summarizes the results.

Table 5: Impact of energy subsidy reform shocks on selected economic variables in the long run

\begin{tabular}{|c|c|c|c|}
\hline \multirow[b]{2}{*}{ Variable } & \multicolumn{3}{|c|}{ Percentage change (departure from baseline) } \\
\hline & $\begin{array}{c}\text { (a) } \\
\text { Pricing reform } \\
50 \%: \\
\text { Household } 50 \% \text {; } \\
\text { Firms }-5 \%\end{array}$ & $\begin{array}{c}\text { (b) } \\
\text { Oil price } \\
\text { decline: }-5 \% ; \\
\text { Pricing reform } \\
50 \%: \\
\text { Household } \\
50 \% ; \\
\text { Firms -5\% }\end{array}$ & $\begin{array}{c}\text { (c) } \\
\text { Oil price decline: } \\
-5 \% \\
\text { Subsidy reform } \\
40 \% ; \\
\text { Competition reform- } \\
20 \% \text {; productivity } \\
\text { boost } 6.5 \%\end{array}$ \\
\hline Macroeconomic indicators & & & \\
\hline Real GDP & -1.43 & -10.10 & 3.62 \\
\hline Real GNP & -3.63 & -13.76 & 0.79 \\
\hline Real exchange rate & 0.39 & -2.62 & -5.54 \\
\hline Real rate of return on capital, gross of tax & 2.88 & -8.39 & -1.11 \\
\hline Capital stock & -2.80 & -3.58 & -1.94 \\
\hline $\begin{array}{l}\text { Non-petroleum exports/GDP } \\
\text { Government }\end{array}$ & -1.18 & 0.53 & 9.20 \\
\hline Fiscal deficit/GDP & 0.35 & -9.66 & -6.31 \\
\hline Welfare payments & 3.70 & 1.70 & -4.16 \\
\hline Current account/GDP & -1.76 & -14.34 & -5.97 \\
\hline $\begin{array}{l}\text { Investment expenditure/GDP } \\
\text { Welfare and consumption }\end{array}$ & 0.98 & 1.91 & 1.33 \\
\hline $\begin{array}{l}\text { Welfare (Real disposable income, CPI } \\
\text { deflated) }\end{array}$ & -7.82 & -5.82 & 7.37 \\
\hline $\begin{array}{l}\text { Household energy consumption } \\
\text { Labour }\end{array}$ & -12.15 & -11.22 & -5.02 \\
\hline Unskilled expatriate labour employment & -0.71 & 1.94 & 19.99 \\
\hline Skilled expatriate labour employment & -0.80 & 1.49 & 16.70 \\
\hline Real Kuwaiti unskilled wage, PC deflated & -4.0 & -4.8 & 19.4 \\
\hline Real Kuwaiti skilled wage, PC deflated & -3.1 & -4.2 & 9.7 \\
\hline Real expatriate unskilled wage, PC deflated & -1.6 & -2.2 & -1.6 \\
\hline $\begin{array}{l}\text { Real expatriate skilled wage, PC deflated } \\
\text { Industry/ oligopoly }\end{array}$ & -1.6 & -2.2 & -1.6 \\
\hline Pre-tax pure profits/GDP & 0.17 & 0.27 & -0.02 \\
\hline Average markup & 0.59 & -0.29 & -3.52 \\
\hline Average markup, non-oil tradables & 0.72 & -0.19 & -2.51 \\
\hline Average markup, non-tradable services & 0.62 & -0.77 & -5.92 \\
\hline Fixed costs/GDP & -0.29 & -0.10 & 0.63 \\
\hline Average industry scale & 18.15 & 5.64 & 37.62 \\
\hline
\end{tabular}

Source: Simulation results.

At the macro level, the real GDP and real GNP drops are driven by a loss in capital stock. The net fiscal effects witness only minor improvements. The increase in the government revenue resulting from savings accrued by reducing subsidies improves the government budget. These savings, however, are offset by higher welfare payment to Kuwaiti citizens to compensate for inflation and for the decline in 
household disposable income caused by the decline in subsidy. Household welfare, measured by real disposable income deflated by the $\mathrm{CPI}$, drops.

The first important insight from the results is that transmission of energy subsidy reform into trade flows occurs through the two main channels, but through opposing effects: (i) raising the cost of local energy and energy-dependent goods; and (ii) appreciating the exchange rate, which decreases the relative cost of imports and reduces the competitiveness of non-oil exports abroad. Nevertheless, these effects are very limited due to idiosyncratic factors, namely: (i) the elasticity of substitution between imports and locally produced goods; (ii) the flexibility of expatriate labour contracts; (iii) high share of imports in intermediates; and (iv) oligopolistic structures in non-tradable and tradable sectors. The dynamics are as follows.

The drop of the subsidy by itself does not affect Kuwait's net petroleum exports. It does, however, raise the cost of domestic energy and energy-dependent goods, as well that of intermediates using local energy as an input. Accordingly, overall household income declines as, consequently, does household demand for energy and other products. As such, both households and industries' (intermediate) demand for these goods also declines. Further, the rise in domestic energy prices causes the real exchange rate to appreciate, which decreases the competitiveness of non-oil exports.

Accordingly, industries adjust their production (downwards), first through labour. The flexibility of expatriate labour contracts allows affected industries to adjust their employment levels, causing similar declines in the employment levels of skilled and unskilled expatriates (while the employment of Kuwaitis is largely unaffected due to their fixed employment in the public sector, while their real wages are reduced). Without employment sponsorship, expatriate labour must exit. As expatriates' wages are generally lower than those of Kuwaitis, their exit contributes to the above-described production adjustments and to potentially smaller adjustments in consumption. This mechanism is unique to GCC states (with similar labour markets) in which expatriates' exit acts as a cushion that absorbs the economic shock.

The mobility of capital in the long run, coupled with the decreased competitiveness of non-oil exports (owing to the appreciating real exchange rate), leads to declines in output for the non-energy sectors, which has a net contractionary effect on the overall economy. This effect is similar to that of the 'Dutch Disease', which occurs following a boom in natural resource exports that leads to a significant appreciation of nominal (and real) exchange rates (or to inflation in countries with fixed exchange rates regimes), adversely affecting non-resource tradable sectors and expanding non-traded service sectors.

At the same time, the appreciating real exchange rate also renders imported goods relatively cheaper. Thus, the declining household demand is moderated with more affordable imports. Similarly, the demand for intermediate goods is inelastic, and the high real exchange rate powered by the strong petroleum exports renders imported intermediate relatively cheaper. As such, there are potential expansion opportunities as local industries shift away from local intermediates to more affordable imported intermediates. Nevertheless, low elasticity of substitution between imports and locally produced goods, coupled with the share of imports in intermediate inputs in the non-energy tradable sectors, means that the expansion in those sectors is small. Overall, the demand for imported intermediate inputs changes, but only marginally. The net effect is a decline in non-energy output and exports, and an increase in overall imports.

The long-term sectoral results, depicted in Table 6, reveal three important insights into the linkages between subsidy reform and the trade of non-oil tradable industries. 
Table 6: Long-run sectoral effects of subsidy reform

\begin{tabular}{lccccc} 
& \multicolumn{5}{c}{ Percentage change (departure from baseline) } \\
\cline { 2 - 6 } Variable & $\begin{array}{c}\text { Expatriate } \\
\text { employment }\end{array}$ & $\begin{array}{c}\text { Gross } \\
\text { output }\end{array}$ & $\begin{array}{c}\text { Markup } \\
\text { ratios }\end{array}$ & Scale & Exports/GDP \\
\hline 1 Agriculture & -0.93 & 0.86 & 0.11 & 4.72 & 0.00 \\
2 Mining & -3.55 & -3.72 & 1.16 & -0.68 & -0.03 \\
3 Crude oil & -5.77 & -3.04 & 0.25 & 14.01 & 1.01 \\
4 Gas and petro-services & -1.61 & -0.73 & 0.01 & 1.05 & 0.00 \\
5 Oil refining & -30.89 & -9.43 & 0.50 & 35.95 & -2.01 \\
6 Chemical & -4.64 & -4.71 & 0.45 & 4.82 & -0.13 \\
7 Light manufacturing & -4.46 & -4.23 & 0.18 & 10.05 & -0.03 \\
8 Heavy manufacturing & -16.93 & -17.55 & 1.22 & 1.42 & -0.38 \\
9 Electricity & -3.35 & -1.37 & 0.49 & 2.42 & 0.00 \\
10 Other network services & -4.25 & -5.26 & 1.83 & -1.83 & -0.25 \\
11 Construction & 9.84 & 9.56 & 0.26 & -3.41 & 0.00 \\
12 Transport & -5.42 & -5.53 & 0.53 & 2.72 & -0.30 \\
13 Financial services & -3.66 & -4.19 & 0.98 & 53.77 & -0.04 \\
14 Other services & -1.05 & -0.80 & 0.05 & 8.27 & -0.01 \\
\hline
\end{tabular}

Source: Simulation results.

First, energy subsidy reform in Kuwait has little in the way of pro-competitive industrial effects and produces few efficiency gains. This result is evidenced by small increases in average markups as a share of GDP, including those for non-oil tradable sectors. It is thus unsurprising that the result is contractionary for the overall economy, achieving losses at both the macro and microeconomic levels. The non-traded 'Construction' industry appears to be the main winner.

Second, non-oil tradable exports do not gain a significant advantage from energy production subsidies. This evidenced by the negligible decline in their exports following energy subsidy reform (a total of 1.18 per cent, a value that is not a significant portion of the overall Kuwaiti exports). Further, if subsidy reform offered a marked edge to non-energy exports, then it is reasonable to expect that following the drop of subsidies, their exports (as a share of output) would decrease by proportionately more than their overall output. Yet the results show that this is not the case for the major non-oil exporters ('Transport', 'Other network services', and 'Chemicals'), and occurs only for small exporters of 'Heavy manufacturing' and 'Services'.

The third insight is that, although the shock reduces economic distortions, there is an increase in oligopoly markups across all industries and the overall economy, which is effectively an increase in distortions. This result requires explanation. The contractionary nature of the shock itself initially reduces oligopoly markups. There are, potentially, expansion opportunities as traded industries shift their output away from the international market to the domestic market. Yet demand in the nonpetroleum exporting and services industries shifts from exports (with the highest elasticity) to intermediate and investment demand (with the lowest and second-lowest elasticity, respectively), causing the overall elasticity of demand to decrease. Oligopoly markups therefore increase in turn, counterbalancing the negative impact of the shocks. This is a very important result because these markups, and the pure profits in the larger industries, remain especially high, implying that a large part of the economy's inefficiency is captured by distortionary oligopoly rents.

These results offer a salient conclusion on linkages between subsidies and trade in oligopolistic economies: local energy subsidies do not offer non-energy exporting sectors a significant advantage in international markets, largely due to the oligopolistic nature of the industries and their ability to secure large markups and pure profits locally. These profits are at risk of being eroded in the international market, so non-oil exporting industries have little incentive to export with or without high energy subsidies at home. 


\subsection{Scenario 2: energy subsidy reform in a low oil price environment}

This analysis quantifies the impact of energy pricing reform (of the type implemented by the Kuwaiti government) on current economic conditions. Thus, this scenario simulates the effects of a 5 per cent drop in the oil export price combined with the subsidy reform shock from the earlier simulation, ${ }^{11}$ adopting the same closures. Table 5 column (b) summarizes the results.

At the macroeconomic level, assuming a continually low oil price, energy pricing reform exacerbates the contractionary shock of the oil price decline. Falls in both real GNP and real GDP are greater than in the first simulation, largely driven a decline in the oil price and a loss in investment. The real exchange rate depreciates, raising the relative cost of intermediate goods. The aggregate welfare measure drops, as real disposable income falls (while savings remain constant), and households adjust their consumption of energy and other products. In compensation, the government increases welfare payments to Kuwaiti citizens, but only by half of that in the first scenario. These payments erode the fiscal improvement obtained through reducing the cost of subsidy payments to households and industries in the long term, necessitating large withdrawals from the KIA funds to finance committed government expenditures.

Importantly, the pro-trade effects of subsidy reform in this scenario are higher than in the first scenario (under a high oil price), driven by the depreciating exchange rate, elasticities of demand, and efficiency improvements through declines in oligopoly markup. The depreciating real exchange rate makes prices of imports increase from the base level, reducing demand for imported final goods and intermediates. The rise in input costs, coupled with the high rise in energy costs, force Kuwaiti non-oil industries to cut costs, especially those of expatriate labour, in the short run, limiting their expansion. Capital flows out of the economy (given the declines in returns locally), which further hurts non-petroleum production and reduces its demand for imported inputs. Consequently, markups of the non-oil non-tradables (such as Construction) also decline to a greater extent. Markup declines entail increasingly competitive pricing that generates an overall positive effect on economic activity and real GDP and have substantial indirect effects that accumulate economy wide. Conversely, this will have only modest direct effects (on final product markups). The ensuing efficiency improvements partially compensate for the output losses of affected industries.

Non-oil exporting industries (such as Chemicals), whose input costs also rise, are directed away from (the least elastic) intermediate and investment demand to (the more elastic) export and final demand. Consequently, their markups decline, expanding their scale efficiency, which further enlarges their expansion. Furthermore, they become more competitive owing to the depreciating exchange rate, enabling them to increase their output and exports. To that end, they import more intermediates and benefit from the movement of expatriate labour and capital away from the negatively impacted nontraded sectors. Additional labour demand is met through hiring additional expatriate workers, who are mobile with flexible employment contracts. All in all, the overall employment level of expatriates increases marginally from that in the initial equilibrium, a result that has critical implications for the labour market and its dependence on international labour mobility. Consequently, both non-oil exports and imports increase because of the majority of intermediate inputs (used by the expanding industries) are imported.

This analysis shows that the pro-trade effects of subsidy reform are limited, but that they are higher if reform is implemented in a low oil price environment because negative effects are partially offset by efficiency gains and reduction in oligopoly markups. Nevertheless, these effects remain small due to structural constraints in economic, labour, and oligopolistic structures. Increases in non-oil industrial production and exports remain insufficient to counter the contractionary effects caused by the oil price

\footnotetext{
The model cannot find solutions when the oil price is reduced beyond $5 \%$ while all economic policies remain in effect. Once some of the model constraints are relaxed, reflecting a change in economic policy regimes, the model then can find solutions for larger reductions in the oil price. These results suggest the unviability of the current economic policies and the difficulty of maintaining these constraints at persistently low oil prices.
} 
decline and subsidy reform, with only minimal improvement in competitiveness from the initial base level.

The pervasiveness of oligopolies that sustain large markups, together with their collusive pricing in the economy, limits trade expansion and suggests that there is considerable scope for competition reform in Kuwait. This is further confirmed by Kuwait's various Five-Year Development Plans, which have the explicit goal of expanding the private sector, coupled with increasing competition within the overall economy. This scope motivates the final analysis, which explores the possible effects of subsidy reform in combination with other reforms.

\subsection{Scenario 3: competition reform and subsidy reform}

This scenario aims to investigate the circumstances in which energy reform could also be accompanied by pro-competitive effects. To illustrate possible policy solutions that could be implemented in combination with energy pricing reform in a low petroleum price environment, this analysis quantifies the effects of the previous two shocks in combination with competition reform, similar to that presented in Shehabi (2017). To that end, two hypothetical competition policy reforms are introduced simultaneously: tighter pricing surveillance that reduces collusive behaviour across all non-petroleum industries, simulated through a 20 per cent reduction in the tendency for businesses to collude on prices (represented by the conjectural variations parameters); and improvements in the productivity of both the private and services sectors of 6.5 per cent in the long run. These sectors are private and services companies (namely all industries with the exception of the hydrocarbon and mining sectors, Electricity, and Agriculture). Table 5 column (c) summarizes the results.

Competition reform can yield substantial improvements in performance, further confirming conclusions obtained by Shehabi (2017), as well as substantial pro-trade effects, as improvements in both imports and non-oil exports can be seen at margins significantly larger than in the previous simulations. Real GDP and real GNP both rise, and output, employment, and aggregate welfare all increase. As in the previous scenario, the transmission of these shocks to households and industries occurs through price and the real exchange rate, whereby initial demand for final and intermediates goods declines, while non-oil exports expand.

Yet in this scenario, competition reform yields noticeable expansion in non-oil output (tradable and nontradable) as well as in non-oil exports. Non-oil exports as a share of GDP increase by as much as 9.2 per cent, which occurs through five main transmission channels:

1. The real exchange rate, which depreciates substantially (approximately twice the depreciation in the previous scenario), not only because of the drop in the oil price, but also due to increases in efficiency. Consequently, firms can increase production scale gains and reduce overall costs.

2. Limiting collusion slashes the large pure profits captured by oligopolies, offering gains distributed across the economy as a whole.

3. Efficiency gains increase the competitiveness of these industries, enabling expansion that exceeds the loss due to increased costs for these industries.

4. In the long run, improvements in efficiency encourage capital stock enlargement, shown as a rebalancing of Kuwait's asset portfolios away from foreign toward domestic productive assets. Unlike the previous scenario, local rates of return on capital change slightly, driven by changes in market capital returns rather than by pure profits, making this scenario beneficial for both workers and capital owners.

5. The increase in productivity of the private sector and services, which further augments the aforementioned efficiency gains; these gains reduce markups further and increase production scale.

With the exception of energy industries and energy-dependent transportation, industries demand additional labour in the long run, which will be mostly filled by expatriate labour (as Kuwaiti workers are largely locked into the public sector). Capital mobility rebalances real rates of return on capital to a level 
only slightly lower than that of the base scenario. Kuwaiti labour gains in the long run, and capital owners do not endure significant losses. Reductions in oligopolies' pure profits as a share of GDP drive increased competitiveness of the overall economy.

Importantly, in industries where large initial markups exist, like the Construction industry, which also uses energy as an input, more competitive pricing generates significant drops in markup. These drops yield effects on overall economic activity that largely exceed the neoclassical gains in allocative efficiency from removing price distortions due to taxes, subsidies, and regulation.

Table 7 summarizes long-term sectoral results.

Table 7: Long- run sectoral effects of subsidy and competition reforms following oil price declines

\begin{tabular}{lccccc}
\hline \multirow{5}{*}{ Variable } & \multicolumn{5}{c}{ Percentage change (departure from baseline) } \\
\cline { 2 - 6 } & $\begin{array}{c}\text { Expatriate } \\
\text { employment }\end{array}$ & $\begin{array}{c}\text { Gross } \\
\text { output }\end{array}$ & $\begin{array}{c}\text { Markup } \\
\text { ratios }\end{array}$ & Scale & Exports/GDP \\
\hline 1 Agriculture & 56.15 & 57.12 & -16.18 & 23.16 & 0.06 \\
$\mathbf{2}$ Mining & 12.46 & 22.69 & -4.28 & 14.76 & 0.63 \\
$\mathbf{3}$ Crude oil & -16.36 & -11.68 & 1.45 & 49.40 & -2.87 \\
$\mathbf{4}$ Gas and petro-services & 23.18 & 17.63 & -0.14 & 0.34 & 0.00 \\
$\mathbf{5}$ Oil refining & -42.10 & -13.94 & 1.09 & 66.85 & -6.29 \\
$\mathbf{6}$ Chemical & 38.92 & 44.23 & -2.54 & 5.70 & 1.10 \\
$\mathbf{7}$ Light manufacturing & 15.58 & 8.94 & 0.08 & -7.68 & 0.02 \\
$\mathbf{8}$ Heavy manufacturing & 25.19 & 19.53 & -0.32 & -4.99 & 0.29 \\
$\mathbf{9}$ Electricity & -21.12 & 17.83 & -8.44 & 47.14 & 0.00 \\
$\mathbf{1 0}$ Other network services & 12.87 & 14.07 & -3.80 & 7.78 & 0.27 \\
$\mathbf{1 1}$ Construction & 13.23 & 16.04 & -0.03 & 2.70 & 0.00 \\
$\mathbf{1 2}$ Transport & 93.11 & 106.93 & -4.79 & 14.18 & 6.38 \\
$\mathbf{1 3}$ Financial services & 23.80 & 17.20 & -1.42 & -7.84 & 0.04 \\
$\mathbf{1 4}$ Other services & 13.01 & 17.18 & -0.80 & 15.86 & 0.40 \\
\hline
\end{tabular}

Source: Simulation results.

Imports also increase substantially, driven by expanded employment, improvement in economic performance, and substantial welfare gains. Households with higher income demand more local and imported products. In turn, non-traded sectors demand more intermediate goods, including imported goods, to meet local increased demand. Similarly, non-oil exporting firms consume more imported intermediates to accommodate their expansion in output and exports.

To demonstrate the large improvement and output gains achieved by competition reform, Figure 8 compares the sectoral changes in exports from this simulation (Scenario 3) with the results of Scenario 1. 
Figure 8: Comparative exports/GDP sectoral results of scenario 1 and scenario 3.

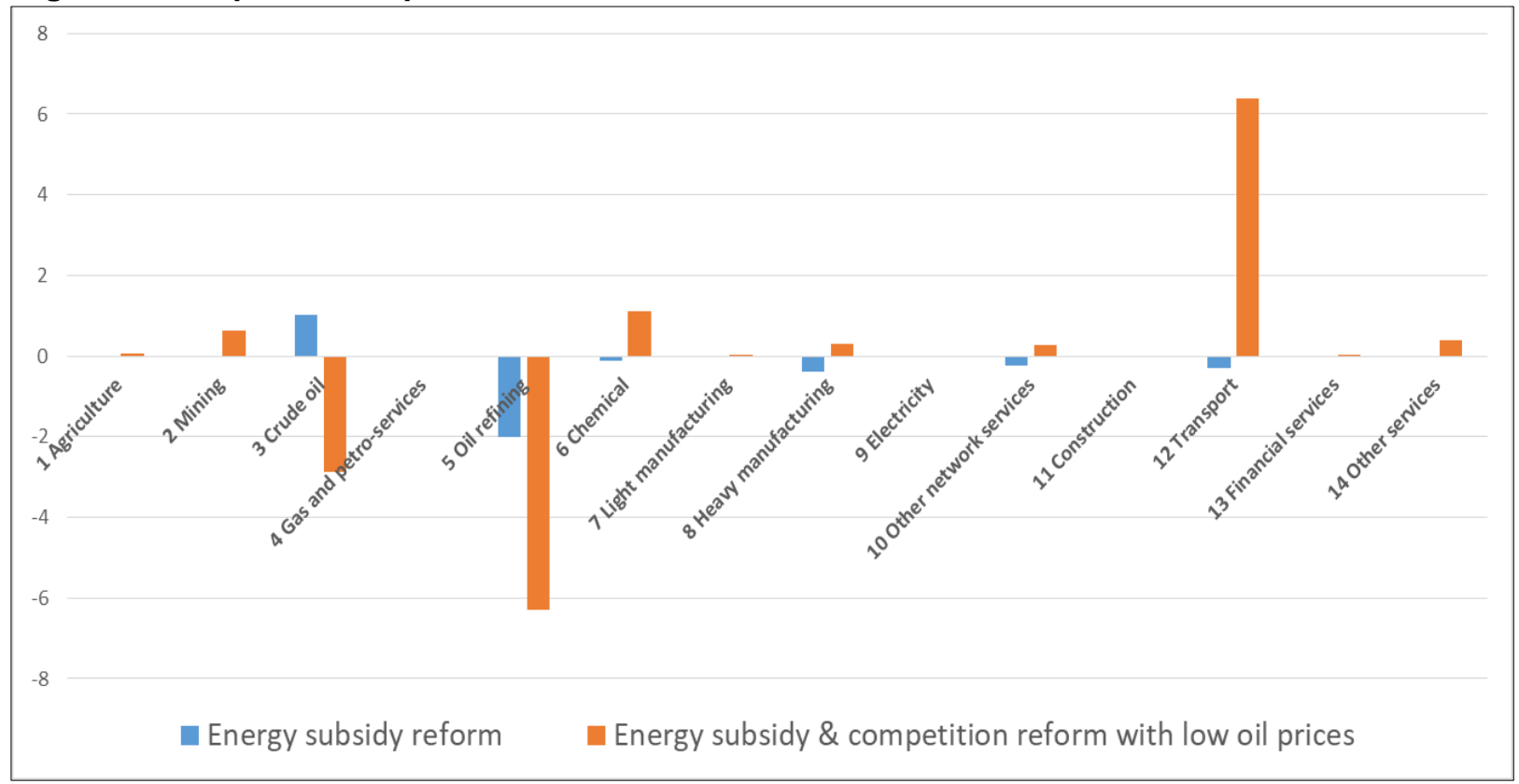

Source: Simulation results.

Similarly, Figure 9 compares sectoral expatriate employment between the two scenarios. The expansion required for firms to expand and is significantly larger than that in the first experiment.

Figure 9. Comparative expatriate employment sectoral results of scenario 1 and scenario 3.

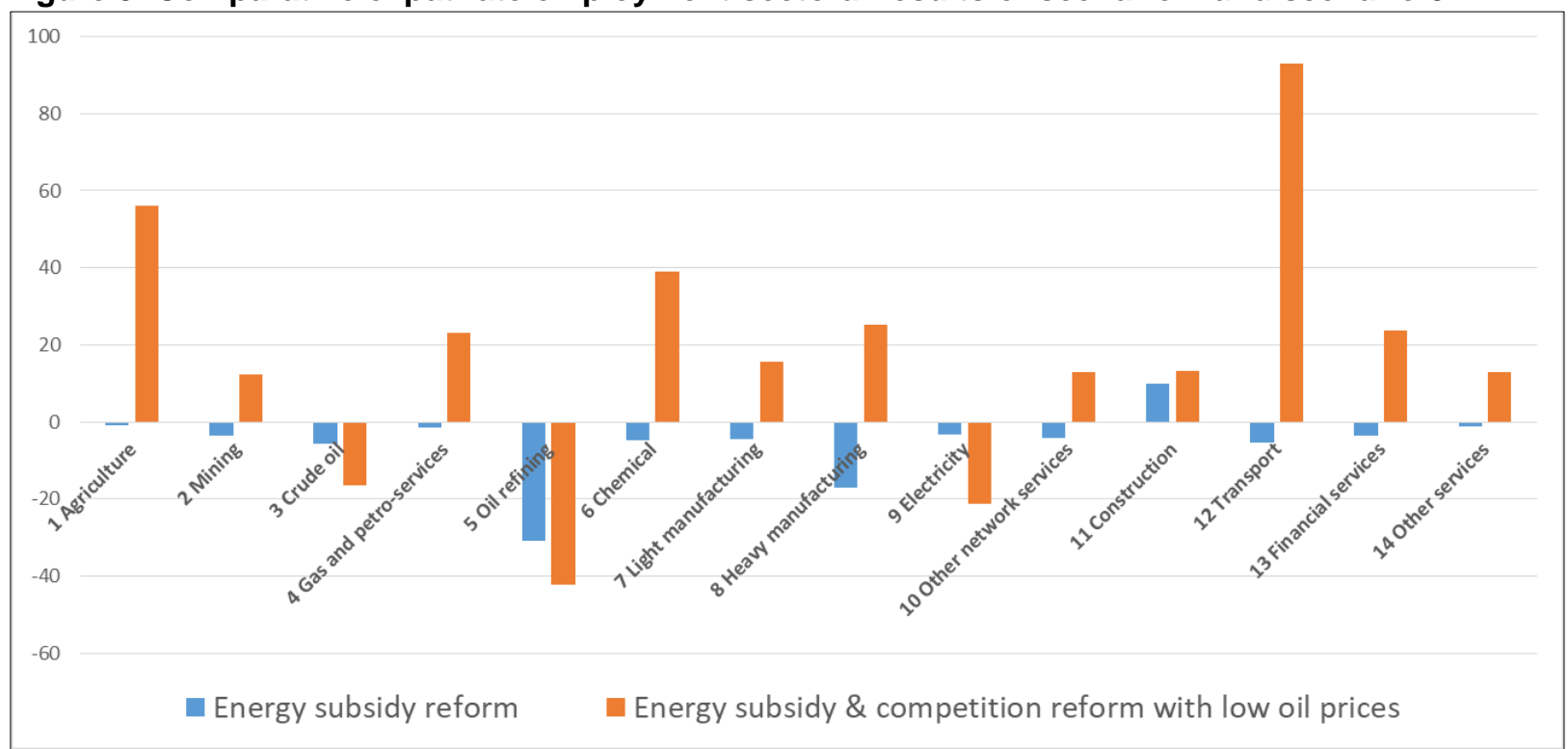

Source: Simulation results.

In summary, the economy faces larger impairments in the long run, caused by the decline of the oil price on the economy. Nonetheless, expansion due to more competitive pricing is particularly relevant as it achieves relative reverse Dutch Disease dynamics as well as expansions in some non-tradable industries, which are sufficient to sustain improvements in the real GDP and achieve significant protrade effects. These effects are not achieved under the previous scenarios. 


\section{Conclusions}

This paper examines the linkages between trade and energy subsidy reform in a distorted, small oildependent economy, using illustrations from Kuwait. There is little evidence on the linkages between trade and subsidy reform in oil-producing economies. In the case of Kuwait, proponents of energy subsidy reform have stipulated that, in a low oil price environment such reform would lead to the expansion of non-oil sectors and their exports. This is the logic of the WTO's use of trade rules to reform subsidies. Sceptics, however, predict that there are limited expansion opportunities, with the consequent expectation of minimal changes in the economic structure or in trade as result of subsidy reform. This paper addresses this gap in the literature. Based on the available information, this analysis is the first to feature trade as a central theme of energy subsidy reform, especially in the context of MENA.

Four major findings emerge from the simulation results.

First, the results show that the transmission of subsidy reform on trade in a highly specialized and distorted economy is negative and occurs through the two main channels of price and appreciation of the real exchange rate; but the effects are largely limited due to existing idiosyncratic economic rigidities and distortions. In certain circumstances, however, these channels can produce the opposite effect, as follows. By raising the costs of energy and energy-dependent goods, subsidy reform appreciates the real exchange rate, which renders imports relatively more affordable while reducing the international competitiveness of non-oil exports. If subsidy reform is applied in a low oil price environment, it worsens the competitive gains of non-energy exports (which result from the depreciating exchange rate) because they cause energy and imported prices to increase. Yet these impacts of subsidy reform on trade are largely limited by four unique factors, namely: rigid public sector employment, oligopolistic distortions, high dependence on imported intermediate inputs in local production, and the limitations of capital movement.

Resource movement occurs only with labour and almost solely with expatriate labour, as capital is immobile in the short run and is restrained in the long run by being largely locked in public industries (including utility companies) or in sovereign wealth funds abroad. Model results show that when subsidy reform is implemented, such economic and structural constraints persist, with little significant change on the composition of trade flows. In addition, the low elasticity of substitution between imports and locally produced goods also means that any expansion in those non-oil energy sectors is small.

Second, relating to concerns over the erosion of industrial competitiveness: simulations show that high energy production subsidies have minimal effects on the international competitiveness of Kuwaiti nonenergy sectors. This result is largely due to the pervasiveness of oligopolies that sustain large markups, together with their collusive pricing in the economy, which limits both trade expansion and incentives to export output. High markups, domestically coupled with the two primary adjustment mechanisms (expatriate labour exit and withdrawals from the SWF), have tended to reduce incentives for efficiencyenhancing structural changes.

Third, subsidy reforms have higher pro-trade effects if implemented in a low oil price environment (but even then, the effects are relatively small) because their negative effects (detailed in the first finding above) are partially offset by efficiency gains and reduction in oligopoly markups. These gains occur as non-oil industries are directed away from the least elastic (intermediate and investment) demand to the more elastic (export and final) demand.

Fourth, subsidy reform worsens the competitive gains of the non-oil sectors in a low-price environment but, in combination with microeconomic reform that manages competition, substantial indirect effects that accumulate economy wide can be achieved, enabling sustained benefits that give opportunities for increased efficiency and trade expansion. The final simulation shows that, with appropriate incentives, the reverse Dutch Disease could be considerably more effective, without becoming a panacea. Policies that manage competition will be of extreme relevance for achieving sustained benefits and structural changes in the long run, enabling opportunities for increased efficiency economy wide, together with expansion of private sector output, employment, and non-oil exports. The accompanying employment 
opportunities also offer possible solutions for the bloated public sector, and for new Kuwaitis entering the labour market, which will have further positive effects on expanding non-oil exports.

These results are arguably more optimistic, in that expansion is constrained by institutional, political, economic, and labour constraints and rigidities. In practice, historic petroleum riches have supported policies that have shifted away from assisting the growth of non-oil sectors towards the funding of welfare payments and public sector employment. The government remains the preferred employer and welfare provider and the public sector dominates in most industries, while investment in non-petroleum tradable sectors remains weak. The hydrocarbon industry continues to dominate both the Kuwaiti economy and governmental revenue sources, causing a large deterioration in the country's fiscal position in the long run. Further, in reality, competition reform is hindered by the existing political economy which governs the dynamics of the business community's ability to influence policy implementation, as well as by economic and regulatory rigidities. As such, absent intentional structural change, these potential benefits cannot be realized.

The results show that, contrary to what the WTO has advanced, subsidy reform in highly specialized oligopolistic oil economies does not lead to pro-trade expansion due to economic and structural constraints. These results have important implications in the policy world. Subsidy reform is very important, so organizations like the WTO ought to use benefits other than the expansion of non-energy trade as a carrot to encourage oil economies to reform their energy subsidies.

The implications of the results point to the potential role of pricing regulation in such small economies in moderating the impact of oil volatility on trade, employment, and overall economic activity. In conclusion, the results potentially suggest a lesson in the sequencing of reforms, and confirm that in developing petro-economies characterized by pervasiveness of oligopolies, microeconomic reform can be a channel through which to achieve pro-trade effects of energy subsidy reform. 


\section{References}

Aghion, P., Akcigit, U., \& Howitt, P. (2013). What do we learn from Schumpeterian growth theory? (NBER working paper No. w18824). Cambridge, MA: National Bureau of Economic Research. Retrieved from http://www.nber.org/papers/w18824.pdf.

Aghion, P., \& Howitt, P. (1992). A model of growth through creative destruction. Econometrica, 60(2), 323-351.

Al-Kaisi, E. (1993). Population and labour in Kuwait economy, the problems and the policies. Kuwait Economic Association, Kuwait.

AISabah, M. S. S. (1985). General equilibrium analysis of government expenditures in an oil exporting country: The case of Kuwait. Unpublished doctoral dissertation. Harvard University, Cambridge, MA.

Al-Sennari, R. (2016, January 4). Al-Kuwayt tadkhul zaman al-ḍarā'ib (Kuwait enters the era of taxes). Al-Ra'i. Retrieved from http://www.alraimedia.com/ar/article/economics/2016/01/04/647157/nr/kuwait

Arze Del Granado, F., Coady, D., \& Gillingham, R. (2012). The unequal benefits of fuel subsidies: A review of evidence for developing countries. World Development, 40(11), 2234-2248. https://doi.org/10.1016/j.worlddev.2012.05.005.

Asano, A., \& Tyers, R. (2015). Third arrow reforms and Japan's economic performance. (UWA Discussion Paper Series DP 15.17). Perth, WA, Australia: University of Western Australia. Retrieved from http://www.business.uwa.edu.au/_data/assets/pdf_file/0012/2765847/15.17Asano,-A.-and-Tyers,-R.-Third-Arrow-Reforms-and-Japans-Economic-Performance.pdf.

Balistreri, E. J., \& Markusen, J. R. (2009). Sub-national differentiation and the role of the firm in optimal international pricing. Economic Modelling, 26(1), 47-62.

Bazilian, M., \& Onyeji, I. (2012). Fossil fuel subsidy removal and inadequate public power supply: Implications for businesses. Energy Policy, 45, 1-5. https://doi.org/10.1016/j.enpol.2012.02.057.

Blanchard, O., \& Giavazzi, F. (2003). Macroeconomic effects of regulation and deregulation in goods and labour markets. The Quarterly Journal of Economics, 118(3), 879-907. https://doi.org/10.1162/00335530360698450.

British Petroleum Company (BP). (2018). BP statistical review of world energy. London: British Petroleum Co.

BuShehri, M. A. M., \& Wohlgenant, M. K. (2012). Measuring the welfare effects of reducing a subsidy on a commodity using micro-models: An application to Kuwait's residential demand for electricity. Energy Economics, 34(2), 419-425. https://doi.org/10.1016/j.eneco.2011.08.001.

Dennis, A. (2016). Household welfare implications of fossil fuel subsidy reforms in developing countries. Energy Policy, 96, 597-606. https://doi.org/10.1016/j.enpol.2016.06.039.

Devarajan, S., \& Rodrik, D. (1991). Pro-competitive effects of trade reform: results from a CGE model of Cameroon. European Economic Review, 35(5), 1157-1184.

Dixon, P., Parmenter, B., Sutton J. \& Vincent D. (1982). ORANI: A Multisectoral Model of the Australian Economy, Contributions to Economic Analysis. New York: North-Holland Publishing Company.

Fattouh, B., \& Mahadeva, L. (2014). Price reform in Kuwait's electricity and water sector: assessing the net benefits in the presence of congestion. OIES paper MEP 9. Oxford: Oxford Institute for Energy Studies.

Farouq, M., \& Mousa, A. (2017, May 8). 225 miliūn dīnār.. ḥasīlat rusūm tahwīlāt al-wāfidīn'. Al-Anbā (225 million dinar total fees on expatriates' remittances', Al-Anba), Kuwait City, Kuwait. 
http://www.alanba.com.kw/ar/economy-news/743686/08-05-2017---مليون-دينار -حصيلة-رسوم-تحويلات الو افدين

Gahvari, F., \& Taheripour, F. (2011). Fiscal reforms in general equilibrium: Theory and an application to the subsidy debate in Iran. Journal of Economic Analysis and Policy, 11(1), 1-54.

Gelan, A. (2018). Economic and environmental impacts of electricity subsidy reform in Kuwait: A general equilibrium analysis. Energy Policy, 112, 381-398. https://doi.org/10.1016/j.enpol.2017.10.032.

Grossman, G. M., \& Helpman, E. (2014). Growth, trade, and inequality. (NBER working paper No. w20502). Cambridge, MA: National Bureau of Economic Research. Retrieved from http://www.nber.org/papers/w20502.

Gunasekera, H. D., \& Tyers, R. (1990). Imperfect competition and returns to scale in a Newly Industrialising Economy: A General Equilibrium Analysis of Korean Trade Policy. Journal of Development Economics, 34, 223-247.

Harris, R. (1984). Applied general equilibrium analysis of small open economies with scale economies and imperfect competition. American Economic Review, 74(5), 1016.

Horridge, M. (1987). The long term costs of protection: experimental analysis with different closures of an Australian computable general equilibrium model. Doctoral dissertation. The University of Melbourne, Melbourne, Australia.

International Energy Agency (IEA) (2018). Outlook for Producer Economies 2018: What do changing energy dynamics means for major oil and gas exporters? Paris: EIA.

International Monetary Fund (IMF) (2013). Kuwait: Selected Issues. IMF Country Report No. 13/337. Washington, D.C.: IMF.

Jensen, J., \& Tarr, D. (2003). Trade, Exchange Rate, and Energy Pricing Reform in Iran: Potentially Large Efficiency Effects and Gains to the Poor. Review of Development Economics, 7(4), 543-562. https://doi.org/10.1111/1467-9361.00208.

Khorshid, M. (1990). A dynamic macroeconomic model for Kuwait: Analysis of the medium-term path. Energy Economics, 12(4), 289-301. https://doi.org/10.1016/0140-9883(90)90019-C.

Khorshid, M. (1991). A Social-accounting-matrix-based Long-term Model for a Gulf Cooperation Council Country: the Kuwaiti Case. Economic Systems Research, 3(3), 299-314. https://doi.org/10.1080/09535319100000023.

Kuwait Central Statistical Bureau. (2017a). Annual general statistics. Kuwait City: State of Kuwait. Kuwait Central Statistical Bureau. (2017b). Foreign Trade Statistics. Kuwait City: State of Kuwait.

Kuwaiti Stock Exchange (2013). Dalïl al-mustathmīr (Industry reports- the Investor's guide). Kuwait City: Author.

Lin, B., \& Li, A. (2012). Impacts of removing fossil fuel subsidies on China: How large and how to mitigate?. Energy, 44(1), 741-749. https://doi.org/10.1016/j.energy.2012.05.018.

Li, Y., Shi, X., \& Su, B. (2017). Economic, social and environmental impacts of fuel subsidies: A revisit of Malaysia. Energy Policy, 110, 51-61. https://doi.org/10.1016/j.enpol.2017.08.015.

Lofgren, H., Harris, R. L., \& Robinson, S. (2002). A standard computable general equilibrium (CGE) model in GAMS. Washington, D.C: International Food Policy Research Institute.

Ministry of Planning. (1990). Statistics Abstract in 25 years. Kuwait City, Kuwait.

Ministry of Planning. (2000). Annual Statistics Abstract. Kuwait City, Kuwait.

Organization of the Petroleum Exporting Countries. (2017). OPEC Annual Statistical Bulletin. Vienna, Austria. Retrieved from https://www.opec.org/opec_web/static_files_project/media/downloads/publications/ASB2017_ 13062017.pdf. 
Plante, M. (2014). The long-run macroeconomic impacts of fuel subsidies. Journal of Development Economics, 107, 129-143.

Public Authority for Civil Information. (2018). Altaqār īr al-'inșāa'iyya (The statistical reports). Kuwait City, Kuwait.

Rentschler, J. (2016). Incidence and impact: The regional variation of poverty effects due to fossil fuel subsidy reform. Energy Policy, 96, 491-503. https://doi.org/10.1016/j.enpol.2016.06.025

Schumpeter, J. A. (1911). The Theory of economic development: An inquiry into profits, capital, credit, interest and the business cycle. Second publication. Harvard University Press: Cambridge, MA.

Schumpeter, J. A. (1942). Capitalism, socialism and democracy. London, UK: Routledge printed 1976.

Segerstrom, P. S., Anant, T. C., \& Dinopoulos, E. (1990). A Schumpeterian model of the product life cycle. The American Economic Review, 1077-1091.

Shehabi, M. (2017). Assessing Kuwaiti energy pricing reforms. OIES Paper MEP 117. Oxford Institute for Energy Studies. Oxford, UK. DOI: 10.26889/9781784670931. https://www.oxfordenergy.org/wpcms/wp-content/uploads/2017/11/Assessing-Kuwaiti-EnergyPricing-Reforms-MEP-17.pdf.

SWF Institute (n.d.). Sovereign Wealth Fund Rankings. Retrieved from https://www.swfinstitute.org/sovereign-wealth-fund-rankings/ (accessed January 2, 2018).

Tyers, R. (2005). Trade reform and manufacturing pricing behavior in four archetype Asia-Pacific economies. Asian Economic Journal, 19(2), 181-203. https://doi.org/10.1111/j.14678381.2005.00209.x.

Tyers, R (2015). Service oligopolies and Australia's economy-wide performance. Australian Economic Review, 48(4): 333-356.

Wazīr al-Māliyya (2016, March 22). 22 milyār dīnār al-'ajz al-mutawaqqa' bi-mīzāniyyat al-dawla fĩ alsanawāt al-3 al-muqbila (The minister of finance: 22 billion dinar is the expected deficit in the state's budget for the next 3 years). Kuwait News Agency.

World Bank (2017). Energy Use, DataBank. World Bank: District of Columbia, USA. 


\section{Appendix A:}

\section{Key modelling specifications}

This appendix complements the description of the model offered in the main text of the paper. It emphasizes the system of taxes and subsidies built into the model as well as the elasticities of its various demand sources.

\section{A.1. Subsidies and tax representation}

In the standard model closure, tax revenue (or subsidy expense) and therefore the fiscal surplus or deficit, is endogenous, determined by the level of economic activity. The government raises tax revenue from both direct and indirect taxation, most rates applied being exogenous and constant (though some can be made endogenous, as needed), but the revenues earned depend on levels of economic activity.

Total tax revenue is then the sum of the individual components, which can be raised from each source as expressed below. Subsidies and governmental transfers will be represented in the same way as taxes, specifying the rates as a negative tax.

\section{Direct income tax revenue}

$T_{Y}=\sum_{i=1}^{N} \tau_{K_{i}}\left(r K_{i}+\pi_{i}\right)+\tau_{U_{K}} w_{U_{K}} L_{U_{K}}+\tau_{S_{K}} w_{S_{K}} L_{S_{K}}+\tau_{U_{N}} w_{U_{N}} L_{U_{N}}+\tau_{S_{N}} w_{S_{N}} L_{S_{N}}$

where $r$ is the home real financing rate (bond yield); $K_{i}$ denotes total capital stock in industry $i$; $\pi_{i}$ denotes total pure profit in industry $i$; and the subscripts ' $U$ ' and ' $S$ ' denote unskilled and skilled labour (production workers and the combination of professionals and para-professionals as per the ILO classification of occupations). The sub-subscripts ' $K$ ' and ' $N$ ' denote Kuwaiti and non-Kuwaiti labour. $\tau$ is the income tax rate applied on income earned by the respective different group of labour.

To represent subsidies, government transfers, and wage assistance, the model would specify $\tau<0$.

Income tax/subsidy rates, to the extent they are applied, are approximated by flat rates deduced as the quotient of revenue and the tax base. Including tax rates even when tax rates are almost negligible enables the capture and assessment of various tax policies.

\section{Import tariff revenue}

$T_{M}=\sum_{i=1}^{N} \tau_{i}^{M}\left(M_{i+} I_{i}^{*}\right) \frac{p_{i}^{w}}{e}$

where $I_{i}^{*}$ is foreign investment in industry $i ; M_{i}$ are imports of industry $l$; and $e$ is the exchange rate.

\section{Export tax revenue}

$T_{X}=\sum_{i=1}^{N}\left(-s_{i}^{X}\right) p_{i} X_{i}$

where $s_{i}^{X}$ denotes the net power of the export subsidy rate in industry $l$; and $X_{i}$ are exports of industry i.

\section{A.2. Demand and demand elasticities}

The elasticity of demand $\left(\varepsilon_{i}\right)$ facing firms in a given industry $i$ is a downward-sloping demand curve that depends on the weighted average of the elasticities of demand in the above-mentioned five markets. Calculating this average depends on the initial shares $S_{i}^{j}$ of the demand facing each industry. Table A.1 calculates the shares drawing upon the SAM data. 
Table A.1: Demand shares per industry 2013

\begin{tabular}{lccccc}
\hline $\begin{array}{l}\text { Industry/ } \\
\text { Percentage }\end{array}$ & Final & Government & Investment & Intermediate & Export \\
\hline 1 Agriculture & 87.1 & 3.2 & 0.0 & 0.2 & 9.5 \\
2 Mining & 8.5 & 56.2 & 0.0 & 1.0 & 34.2 \\
3 Crude oil & 1.7 & 49.3 & 0.0 & 0.9 & 48.2 \\
4 Gas and petro-services & 7.6 & 0.0 & 0.0 & 0.7 & 91.8 \\
5 Oil refining & 8.1 & 71.7 & 0.0 & 3.6 & 16.7 \\
6 Chemical & 8.3 & 55.8 & 0.0 & 15.8 & 20.1 \\
7 Light manufacturing & 48.4 & 9.5 & 0.0 & 4.0 & 38.1 \\
8 Heavy manufacturing & 12.6 & 35.6 & 0.0 & 27.9 & 23.9 \\
9 Electricity & 96.5 & 0.0 & 0.0 & 0.0 & 3.5 \\
10 Other network services & 41.9 & 33.8 & 0.0 & 0.0 & 24.4 \\
11 Construction & 0.0 & 0.0 & 0.0 & 96.1 & 3.9 \\
12 Transport & 44.0 & 36.3 & 0.0 & 0.0 & 19.7 \\
13 Financial services & 19.6 & 4.3 & 0.0 & 0.0 & 76.2 \\
14 Other services & 45.5 & 2.3 & 47.4 & 0.9 & 3.9 \\
\hline
\end{tabular}

Source: Author's CGE model database (SAM) constructed for 2013.

In addition, the elasticity depends on component elasticities of substitution, firm numbers (which are assumed exogenous in analysis in this paper), and the conjectural variation parameters in industry $i$ $\left(\mu_{i}\right)$. The conjectural variation relationship allows firms to collude on price, so the overall oligopoly pricing choice is determined by the influence of pricing choices made by any individual firm $k$ on the price set by firm $j$.

The demand elasticities depend on the structure of the model. They are essential to the capture of oligopoly behaviour since they determine the size of markup ratios via an exchange rate equation in the model (which follows a standard definition of the common currency ratio of the home and foreign GDP price levels), while investment expenditure is also impacted by local and foreign interest rates.

For example, 'final demand' (superscript $F$ ) spends its post-tax income on foreign-sourced products differentiated from home products (subscript $H$ ) with elasticity of substitution $\sigma_{i}^{F}>0$, as well as on local varieties that are differentiated from one another with elasticity of substitution $\eta_{i}^{F}$. As such, final demand for variety $j$ of home product group $i$ is:

$D_{i H_{j}}=\frac{a_{i}^{F} \delta_{i}^{F}}{n_{i}}\left(\frac{Y-T_{Y}}{\hat{P}_{i}^{F}}\right)\left(\frac{\hat{P}_{i H}}{\hat{P}_{i}^{F}}\right)^{-\sigma_{i}^{F}}\left(\frac{p_{i H_{j}}}{\hat{P}_{i H}}\right)^{-\eta_{i}^{F}}$,

Where $a_{i}^{F}$ is the calibrated reference expenditure share of product group $i ; \delta_{i}^{F}$ is the corresponding share of domestic goods in final demand for product group $i$; and $Y$ is total income (being GNP); while $T_{Y}$ is the total direct income tax paid on $Y$.

Therefore, the final demand elasticity is expressed as follows:

$\varepsilon_{i}^{F}=-\eta_{i}^{F}+\frac{1}{n_{i}}\left\{\left(\sigma_{i}^{F}-1\right) \delta_{i}^{F}\left(\frac{\widehat{P}_{i H}}{\widehat{P}_{i}^{F}}\right)^{\left(1-\sigma_{i}^{F}\right)}+\left(\eta_{i}^{F}-\sigma_{i}^{F}\right)\left(1+\left(n_{i}-1\right) \mu_{i}\right)\right\}$,

where $\eta_{i}^{F}$ is the elasticity of substitution of final demand across home varieties in sector $i ; n_{i}$ is the number of firms in industry $i ; \delta_{i}^{F}$ is the home share in final demand for product $i ; \sigma_{i}^{F}$ is the elasticity of substitution of final demand for good $i$ between domestic and foreign countries; $n_{i}$ is the number of domestic firms in industry $i ; \hat{P}_{i H}$ is the CES composite price of all home varieties of product $i$; and $\hat{P}_{i}^{F}$ is the CES composite of home and foreign final product prices in the domestic market, weighted by domestic consumption shares. 
The behaviour of government consumption and the expenditure of the capital goods sector on home and foreign products are similar, except that the government pays no import duties or consumption tax and the capital goods sector pays no import duties.

Intermediate demands for home-produced varieties of the intermediate goods in industry $i\left(T_{i}\right)$ and for the imported goods $\left(T_{i}^{*}\right)$, respectively, are:

$T_{i}=\sum_{j=1}^{N} A_{i j} Q_{j} \quad$ and $\quad T_{i}^{*}=\sum_{j=1}^{N} A_{i j}^{*} Q_{j} \quad \forall j$.

The elasticity of intermediate demand is as follows:

$\varepsilon_{i}^{T}=\sum_{j=1}^{n_{i}} S_{i j}^{T}\left[-\eta_{i}^{T}+\frac{1}{n_{i}}\left(\gamma_{i j}+\sigma_{i}^{T}-1\right) \phi_{i j}\left(\frac{\hat{P}_{i H}}{\hat{P}_{i}^{T}}\right)^{\left(1-\sigma_{i}^{T}\right)}+\left(\eta_{i}^{T}-\sigma_{i}^{T}\right)\left(1+\left(n_{i}-1\right) \mu_{i}\right)\right]$,

where $S_{i j}^{T}$ is the share of industry $j$ in the total intermediate demand for input $i$; and $\hat{P}_{i}^{I}$ is the CES composite of home and foreign intermediate product prices in the domestic market, weighted by domestic intermediate consumption shares.

Table A.2 lists initial demand elasticities per sector, calculated using the model equations.

Table A.2: Initial demand elasticities and markups per sector

\begin{tabular}{lcccccc}
\hline Industry & Final & Government & Investment & Intermediate & Exports & $\begin{array}{c}\text { Weighted } \\
\text { average } \\
\text { elasticity }\end{array}$ \\
\hline 1 Agriculture & -1.8 & -4.7 & -3.0 & -3.0 & -8.5 & -2.2 \\
$\mathbf{2}$ Mining & -1.0 & -3.6 & -1.0 & -3.0 & -4.0 & -3.4 \\
$\mathbf{3}$ Crude oil & -1.0 & -3.5 & -1.0 & -12.0 & -14.1 & -12.8 \\
$\mathbf{4}$ Gas and petro- & & & & & & \\
services & -3.6 & -4.8 & -2.1 & -30.0 & -15.0 & -25.6 \\
$\mathbf{5}$ Oil refining & -7.8 & -5.7 & -4.7 & -20.0 & -12.2 & -12.9 \\
$\mathbf{6}$ Chemical & -7.1 & -5.4 & -2.9 & -8.0 & -7.8 & -7.0 \\
$\mathbf{7}$ Light manufacturing & -5.3 & -12.0 & -6.0 & -12.0 & -16.6 & -8.9 \\
$\mathbf{8}$ Heavy & & & & & & \\
manufacturing & -5.5 & -5.4 & -3.5 & -12.0 & -15.0 & -9.9 \\
$\mathbf{9}$ Electricity & -3.8 & -3.6 & -1.8 & -33.0 & -4.7 & -4.6 \\
$\mathbf{1 0}$ Other network & & & & & & \\
services & -1.0 & -2.5 & -1.5 & -5.0 & -3.8 & -2.9 \\
$\mathbf{1 1}$ Construction & -5.1 & -5.1 & -4.9 & -20.0 & -6.2 & -5.5 \\
$\mathbf{1 2}$ Transport & -4.2 & -5.6 & -2.9 & -3.0 & -8.3 & -5.5 \\
$\mathbf{1 3}$ Financial services & -6.5 & -7.0 & -3.5 & -5.0 & -8.6 & -5.4 \\
14 Other services & -5.4 & -4.8 & -2.0 & -5.0 & -12.7 & -5.2 \\
\hline
\end{tabular}

Source: Author's CGE model calculations.

\section{A.3. Domestic prices of imported goods}

The formulation of these is as follows:

$p_{i}^{*}=\frac{p_{i}^{w}\left(1+\tau_{i}^{M}\right)\left(1+\tau_{i}^{C}\right)}{e}$,

Where $p_{i}^{w}$ is the exogenous foreign currency price of goods imported by Kuwait and produced in the rest of the world; $\tau_{i}^{M}$ is the ad valorem tariff rate; $\tau_{i}^{C}$ is the consumption tax rate on final demand for the products of industry $i$; and $e$ is the exchange rate. 


\section{A.4. Domestic prices of home products}

These are marked up over average variable cost. The production function is Cobb-Douglas in variable factors and inputs, with output elasticities $\alpha_{i}$ for capital, $B_{k i}$ for factors $k$, and $\gamma_{j i}$ for inputs $j$, and the subaggregation of imported and domestic inputs is CES. The unit variable costs is calculated with reference to $\hat{P}_{j i}^{I}$, are a CES composite of home and imported input prices weighted by the domestic and imported shares specific to consuming industry $i$. It is expressed as:

$\hat{P}_{j i}^{I}=\left[\phi_{j i}\left(p_{j}\right)^{\left(1-\sigma_{j}^{I}\right)}+\left(1-\phi_{j i}\right)\left(p_{j}^{*}\right)^{\left(1-\sigma_{j}^{I}\right)}\right]^{\frac{1}{\left(1-\sigma_{j}^{I}\right)}}$,

where $\phi_{j i}$ is the domestic share of inputs from industry $j$ used by industry $i$. This relationship implies that domestic producer prices are simply higher by the markup, $m_{i}: p_{i}=m_{i} v_{i}, \quad \forall i$.

\section{A.5. Prices of home product exports in foreign markets}

These prices are in foreign currency, so they depend on the home producer price, the exchange rate, the export subsidy rate $S_{i}^{X}$, and the foreign import tariff rate, $\tau_{i}^{* M}$, expressed as:

$p_{i}^{e}=\frac{p_{i} e\left(1+\tau_{i}^{* M}\right)}{\left(1+S_{i}^{X}\right)}, \quad \forall i$.

\section{A.6. GNP and GDP}

The model calculates national income (GNP) as the sum of payments made to domestically owned factors of production. It also accounts for the home share of any net profits (or losses) made; net income from indirect taxation; revenue from direct (income) taxation $T_{Y}$; and net inflows from abroad denoted as $B$. The formulation is, thus, as follows.

$$
Y=r K_{D}+\sum_{k=1}^{K} w_{k} L_{k}+\left(\frac{K_{D}}{K_{T}}\right) \sum_{i=1}^{N} \pi_{i}+\left(T-T_{Y}\right)+\frac{B}{e}+\left(1-\frac{K_{D}}{K_{T}}\right) \tau_{K}^{*}\left(r\left(K_{T}-K_{D}\right)+\sum_{i=1}^{N} \pi_{i}\right) .
$$

In effect, $B$ is the net income component of the current account and unrequited transfers.

GDP measures only income from production in the domestic economy. Therefore, in the model, its calculation excludes factor payments as well as other flows to and from abroad, as follows:

$G D P=r K_{T}+\sum_{k=1}^{K} w_{k} L_{k}+\sum_{i=1}^{N} \pi_{i}+\left(T-T_{Y}\right)$.

\section{A.7. Real exchange rate}

The model allows the measurement of variable economic variables in real terms. The real exchange rate measures the home and foreign GDP price levels, expressed in a common currency. The model, thus, calculates the real exchange rate as the ratio of the home price $\left(P_{Y}\right)$ of a bundle of (traded and non-traded) goods and services at home relative to that abroad $\left(P^{*} y\right)$, as follows:

$e_{R}=\frac{P_{Y}}{\left(\frac{P_{Y}^{*}}{E}\right)}=E \frac{P_{Y}}{P_{Y}^{*}}$,

where $e_{R}$ is the real exchange rate and $E$ is the nominal exchange rate, both expressed according to the financial convention. 